Philosophie ANTIQUE

\section{Philosophie antique}

Problèmes, Renaissances, Usages

19 | 2019

L'épicurisme antique

\title{
In search of an epicurean catharsis
}

Epicurus' treatment of pity and fear

\section{Enrico Piergiacomi}

\section{CpenEdition}

Journals

Electronic version

URL: https://journals.openedition.org/philosant/3161

DOI: 10.4000/philosant.3161

ISSN: 2648-2789

\section{Publisher}

Éditions Vrin

\section{Printed version}

Date of publication: 31 October 2019

Number of pages: 117-150

ISBN: 978-2-7574-2534-3

ISSN: 1634-4561

\section{Electronic reference}

Enrico Piergiacomi, "In search of an epicurean catharsis", Philosophie antique [Online], 19 | 2019, Online since 31 October 2020, connection on 02 December 2022. URL: http://journals.openedition.org/ philosant/3161 ; DOI: https://doi.org/10.4000/philosant.3161

\section{(c) $\Theta \Theta \Theta$}

Creative Commons - Attribution-NonCommercial-NoDerivatives 4.0 International - CC BY-NC-ND 4.0 https://creativecommons.org/licenses/by-nc-nd/4.0/ 


\section{IN SEARCH OF AN EPICUREAN CATHARSIS Epicurus' treatment of pity and fear}

Enrico Piergiacomi

University of Trento / Bruno Kessler Foundation

enrico_piergiacomi@libero.it

RÉSUMÉ. De nombreuses recherches ont mis en évidence le fait que les épicuriens n'étaient pas complètement hostiles à la poésie en général mais qu'ils refusaient probablement les compositions ou procédures poétiques qui ne conduisent pas à la fin naturelle du plaisir « catastématique », c'est-à-dire le bonheur. Dans cet article, nous nous demanderons donc si les épicuriens ont inventé une poésie cathartique de type positif ou s'ils ont simplement rejeté toutes les formes de catharsis poétique en les décrivant comme des expériences négatives. Nous constaterons dans ce travail de recherche, divisé en trois parties, que la première hypothèse est plus probable que la seconde. Dans un premier temps, nous démontrerons que les épicuriens ont effectivement reconnu l'existence d'une catharsis positive, transmise par la raison et l'enseignement de la philosophie, ayant la capacité de faire disparaître les émotions négatives qui entravent l'accès au bonheur (l'amour, la peur du divin, le désir excessif, etc.). L'idée développée, dans un second temps, établit qu'Épicure et ses disciples pourraient s'être opposés à la catharsis tragique décrite dans la Poétique d'Aristote, parce qu'elle implique de passer par des passions négatives telles que la pitié et la terreur. Cette expérience esthétique entrerait alors en contradiction avec l'idéal épicurien du plaisir comme absence de trouble et d'inquiétude psychique. Enfin, dans un troisième temps, nous exposerons l'idée selon laquelle les épicuriens pourraient avoir accepté une seule forme de catharsis poétique : celle facilitant le processus de purification effectué par la raison et l'enseignement de la philosophie. Un exemple possible de cette pratique est le poème De rerum natura de Lucrèce dans lequel la poésie n'est pas considérée comme cathartique en soi, mais si et seulement si elle assiste la philosophie épicurienne dans sa conquête du bonheur.

SUMMARY. Recent scholarship has stressed the fact that the Epicureans were not hostile to poetry in general. It is more probable that these philosophers rejected only those poetic compositions, processes and devices that do not lead to the goal of 'katastematic' pleasure, i.e. to happiness. In the light of this premise, the paper investigates whether the

Philosophie antique, ${ }^{\circ} 19$ (2019), 117-150 
Epicureans recognized a positive cathartic poetry, or whether they simply rejected all forms of poetic catharsis as harmful experiences. It is argued that the former hypothesis is more probable. In order to prove this point, the paper is divided into three parts. Part 1 shows that the Epicureans recognized the existence of a positive catharsis, namely that conveyed by reason and teaching, which are capable of dispelling from the mind those damaging emotions (love, fear of the divine, excessive desire, etc.) that hinder the achievement of happiness, or 'katastematic' pleasure. Part 2 shows that Epicurus and his pupils would surely have rejected the catharsis of tragedy described in Aristotle's Poetics, because this experience conflicts with many key doctrines of Epicureanism and is not pleasurable in the proper Epicurean sense. Part 3 proposes that the only possible kind of poetic catharsis that the Epicureans could have admitted is the one that aids reason and teaching in exercising their cleansing effects. A possible example of this practice consists in Lucretius' poem De rerum natura, where poetry is not considered cathartic per se, but only when it assists Epicurean philosophy in its quest for happiness. 


\section{Introduction $^{*}$}

It is often argued that the Epicureans were fierce enemies of poetry and were critical of its usefulness. This opinion appears only partially true. The Epicureans were surely critical of all aesthetic experiences that give puerilis delectatio and lack what Torquatus called solida utilitas: knowledge of what leads human beings to happiness ${ }^{1}$. If poetry - together with all the other traditional disciplines of Greek $\pi \alpha 1 \delta \varepsilon i ́ \alpha$ - is cultivated as a proper means for pleasure, however, it is acceptable even to Epicureans. It is attested, after all, that Epicurus, Metrodorus, Philodemus and Lucretius agreed to use poetic diction, to tell tales or even write poems ${ }^{2}$. This evidence supports the more cautious hypothesis that the Epicureans were still interested in reinterpreting poetry as an instrument for the achievement of the good of pleasure.

Having established this general point, I would like to investigate a very specific problem. What would the Epicureans have made of the conception of poetic catharsis? Would they have interpreted it just as a form of poetry which totally lacks solida utilitas, or as one that may be refined as a philosophical means for pleasure? I will try to give an answer through a study of surviving Epicurean texts and by drawing a comparison with famous ancient treatises that describe the utility of tragic catharsis: Aristotle's Poetics and book VIII of the Politics. As we will see, there are reasons to suppose that the

* The title of this essay is a conscious echo of Porter 1996. A previous version of the paper was delivered at a philosophical workshop at New York University Abu Dhabi. I thank Phillip Mitsis and the other participants for their useful suggestions for improvement. I am also grateful to the anonymous referee of the journal Philosophie antique, who has provided plenty of comments that have helped me to avoid many mistakes and simplifications, as well as to express my ideas more clearly. I remain responsible for any errors that might remain in the text.

1. Cicero, Fin. I 21.71. See e.g. Porter 1996, Pace 2009, p. 235-246.

2. See texts and arguments in Giancotti 1978 p. 18-65 and 331-368, Asmis 1995a p. 18-30, Sider 1995, Wigodsky 1995, Gentilucci 1997, Beer 2009, p. 70-78, Halliwell 2011, p. 314-319, Roskam 2011. See also the caveat of Arrighetti 1998, p. 16-20. 
Epicureans attacked one or both of these Peripatetic works. Therefore, this criticism may hint at what an Epicurean cathartic poetry must not be.

My case must begin with a simple question. If catharsis is in the most trivial sense a sort of "purification", then we need to establish whether the Epicureans struggled for a form of "purity" and, if so, we need to define it. This point is fulfilled in $₫ 1$, while the possible Epicurean criticism of Aristotle's poetic treatises and the highly speculative hypothesis of the existence of an Epicurean poetic catharsis are investigated in $\$ 2$ and $₫ 3$ of the essay.

\section{Epicurean purity}

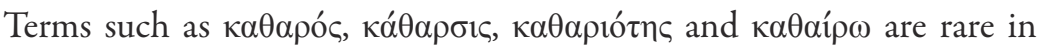
Epicurean fragments or writings. In most cases, they carry no philosophical meaning, but rather indicate the solution, clarification or explanation of a specific issue 3 . In Hermarchus (fr. 34, ed. Longo Auricchio $1988=$ Porphyrius Abst.9.3-4), кá $\theta \alpha \rho \sigma ı \varsigma$ refers to the punishment that the first lawgivers meted out to those who committed homicide, in order to prevent similar acts from occurring in the future. In a fragment of Epicurus' book XXV of On Nature, the author acknowledges the existence of some beings that are only partially responsible for their behavior (e.g. wild animals) and which are "purified", in the sense that they are absolved or excused for their actions, since they cannot change them even through admonitions, corrections and the method of the carrot-and-stick ${ }^{4}$.

There are, however, other instances of these terms which might be relevant to our topic, insofar as they possibly express a form of catharsis that leads to pleasure and happiness. We find three clear examples in Epicurus.

The first is a fragment of his lost letter to his pupil Apelles. The latter is praised here by Epicurus for having cultivated philosophy while remaining

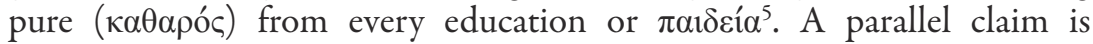
Philodemus' affirmation in the Depietate. The Epicurean claims here that those who philosophize «in a pure manner» $(\kappa \alpha \theta \alpha[\rho \hat{\omega} \varsigma \varphi 1] \lambda$ oбo $\varphi \varepsilon \hat{i}[v])$ correctly perceive the nature of the gods: for they do not distort their theological views through the false tales of the poets ${ }^{6}$. This form of purity is probably also the condition which allows the Epicureans to harbor "pure" conceptions of the

3. Epicurus, Ep.Hdt. 83, Ep.Pyt. 87-88, Nat.11 (= Fr.[26.45]), Nat.25 (= Fr.[34.30], Laursen 1997 p. 42), Nat.34 col. 15 (ed. Leone 2002); Philodemus Lib. fr. 46 (ed. Konstan 1998); Diogenes of Oenoanda frr. 23 I, 43 I (ed. Smith 1993). Epicurus fragments are quoted from the edition of Arrighetti 1973.

4. Cf. Nat.25 (= Fr.[34.25], Laursen 1997, p. 29-31), ed. Hammerstaedt 2003, p. 152-153.

5. The source is Athenaeus XIII 588a (= Fr.[43]). This declaration does not imply a rejection of the entire traditional education, but only its adaptation as a means to pleasure. See Bignone 1973 p. 95-120, Nussbaum 1994, p. 120-124, Asmis 2009. The idea that catharsis is involved here was already recognized by Beer 2009, p. $421 \mathrm{n} .71$.

6. See col. 46.1306-1316 (ed. Obbink 1996) with Arrighetti 2000, p. 24-26. 
divine. Only the pure could perceive the pure. Philodemus' De pietate not only states this point in coll. 9.236-243 and 26.751-27.765, but also explains in col. 45.1292-1305 what such purity entails. Here we find an opposition between the wise men who have pure theological ideas and those who do not respect the preconception ( $\left.\pi \rho{ }^{\prime} \lambda \eta \psi 1 \varsigma\right)$ about the gods. In short, possessing a preconception of the gods means possessing the clear notion that a deity is blessed and immortal, as well as never affirming anything which disagrees with these properties (e.g. by attributing a providential action to the divine) ${ }^{7}$. Given this, it may be the case that what Philodemus has in mind here is a kind of "cognitive" purity. Individuals are pure when they hold true opinions on the divine nature, and impure when they hold false ones, in other words when they develop false beliefs that destroy the majesty of the gods (Epicurus Ep.Her. 77).

Since poetry which distorts the right knowledge of the divine was one of the key features of Greek education, Philodemus' De pietate actually explains what kind of $\pi \alpha 1 \delta \varepsilon i ́ \alpha$ was rejected by Epicurus in his letter to Apelles. What is not accepted is poetic writings or tales that generate false ideas of the divine. In this sense, being ignorant of, or «pure from», this education is paradoxically a form of knowledge and wisdom.

Let us now move on the second text by Epicurus which seems to allude to a form of catharsis. This is Sent.Vat.63:

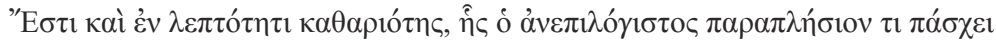

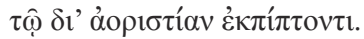

There is also a purity in frugality and the man who has not reasoned it through is in like case with him who errs through excess (trans. Bailey 1926, p. 117, modified).

Epicurus here condemns excessive frugality, which produces effects

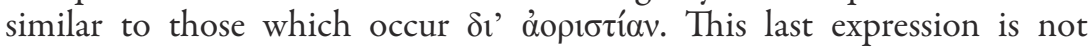
explained by the sentence, but its meaning is clarified by other fragments. Sent.Vat. 59 explicitly states that $\alpha$ opı $\tau$ tí indicates the boundless desire for something (in this case, food) which is caused by a wrong opinion (the same concept occurs in Sent. XV): e.g. the opinion that feasting and eating incessantly is a good thing ( $c f$. the criticism of this belief in Epicurus Ep.Men. 132). And such behavior is a cause of turmoil in and of itself. After all, other fragments report that ignoring the limits set by nature is a stressful experience, and by contrast that the respecting of these same $\pi \dot{\varepsilon} \rho \alpha \tau \alpha$ leads to happiness ${ }^{8}$. Having established this, it appears clear that, when Epicurus says that exces-

7. For some proof and textual evidence, see Essler 2011, p. 148-187; Tsouna 2016.

8. Cf. Epicurus, Sent. X, XVIII and XX-XXI, as well as Nat.25 (= Fr.[34.19], Laursen 1995 p. 102), Konstan 2007, p. 98-100, 157-160. Cf. also Carneiscus Philosophus col. 19 (ed. and comm. of Capasso 1988, p. 261-262). 


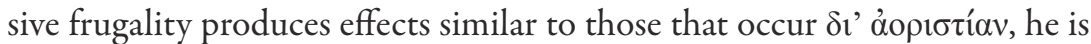
claiming something of this sort. Limiting our desires too much (for example, by trying to suppress even natural/necessary ones, whose fulfillment is necessary for happiness, health and the preservation of life: $c f$. Epicurus Ep.Men. 128 ) is as disturbing as cultivating them ad infinitum. Therefore, we should avoid suppressing all our tendencies and practicing extreme asceticism.

Sent.Vat. 63 makes two points of interest for our investigation. One is

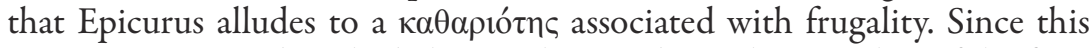
"purity" is opposed to the behavior that produces the same harmful effects as those occurring $\delta t^{\prime}$ a ooplotíav, by this term he probably means the ideal state we have already identified: the state of moderate cultivation of our desires. Being pure with respect to frugality might indicate, in other words, the disposition to avoid excessive renunciations and limitations. What is

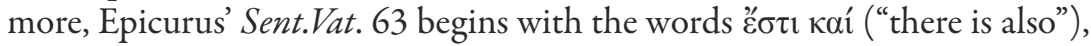

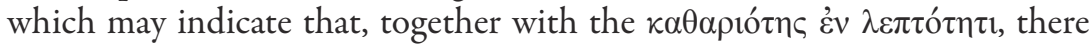
exists also a purity in profligacy. Just as a person is "pure" when he/she avoids suppressing all his/her ambitions, so a person is pure when he/she manages not to follow every single one of them ${ }^{9}$. Catharsis or purification, then, is a matter of equilibrium with respect to our intimate desires.

The second interesting point is that, once again, the purity or кa $\alpha \alpha \rho$ ótnc of frugality has a cognitive basis. Sent.Vat. 63 explicitly affirms that a person falls into this state when he/she is unable to evaluate the inevitable disadvantages of this behavior through reason ( $c f . \dot{\alpha} v \varepsilon \pi i \lambda o ́ \gamma 1 \sigma \tau o \varsigma)$. It is controversial

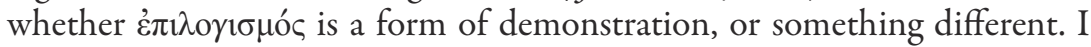
agree with Tsouna that it indicates a kind of survey, assessment or appraisal of the phenomena that allow us to make further inferences ${ }^{10}$. If this scholar is right, Sent.Vat. 63 implies that catharsis is achieved through a rational evaluation of what would be the right behavior. Epicurus infers here that the latter consists in a middle path between excess and deficiency in relation to the fulfillment of desires, based on awareness of the harm that comes from both extremes. If an individual is too prone to asceticism, he or she must be invited to exercise his or her $\dot{\varepsilon} \pi \lambda \lambda \sigma \gamma ı \mu$ ó $\zeta$ better, in order to understand that excessive renunciation will eventually prove harmful.

The third and final fragment that is useful for our investigation is once again preserved in Philodemus' De pietate. The latter text quotes a piece from a letter of Epicurus to Polyaenus, where he declares his intention to lead a pure life with his slave Matro ${ }^{11}$. Even here the philosopher is not explicit

9. It might be useful to recall Philodemus, Rh.7 col. 37.7-8, p. 34 (ed. Sudhaus 1964, vol.

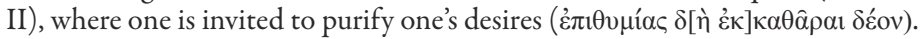

10. Cf. Tsouna 2007, p. 55-60.

11. Philodemus, De piet. col.33.932-937 (= Epicurus, Fr.[115]), Polyaenus Epicureus fr. 51 (ed. Tepedino Guerra 1991). On Matro, $c f$. Obbink 1996, p. 447-450. 
about the meaning of this "purity". I suppose that Epicurus is alluding to the cleansing of the passions which could hinder a good interpersonal relationship. This hypothesis is supported by Lucretius ${ }^{12}$ and Philodemus ${ }^{13}$. Both authors report that Epicurus' teachings free the mind from harmful emotions (like folly, desire ${ }^{14}$, love ${ }^{15}$, greed, fear, pride, and envy) that prevent us from living well in association with others, while calling this cleansing a «purification » and the Epicurean teacher a «purifier». The reward for this process of purification consists in the achievement of pure pleasure. Proof of this is that the removal of such passions offers precisely this kind of i்ovń. Lucretius reports that human beings who engage in sexual intercourse (that is, without feelings of love) experience pleasures that appear purer if compared to those felt by men and women who are love-sick (4.1073-1083). And Diogenes of Oenoanda claims the same thing by comparing the purer pleasurable lives of those immune from envy ${ }^{16}$.

It is not immediately clear how we should interpret the epithet "pure" in relation to pleasure. I suppose that it might be a reference to the katastematic pleasure of $\alpha \tau \alpha \rho \alpha \xi i \alpha$, since this is the necessary outcome of the removal of the psychic turmoil caused by passions (Epicurus, Fr.[7] = Diogenes Laertius, X 136). To consider just a single example, let us return to Lucretius' case of the love-sick person in 4.1073-1083. The pleasure that the latter experiences during sex is less pure because it is mixed with the pain and madness caused by the irrational desire to merge with the body of his or her partner. By contrast, the man or woman who does not feel love is immune from this, and from any kind of anxiety/fear (4.1192-1208). Hence, during sexual intercourse, he or she only feels voluptas. If we also agree with those interpreters who claim that kinetic pleasures follow and "vary" the katastematic pleasure ${ }^{17}$, we could add that the pure pleasure of $\alpha \tau \alpha \rho \alpha \xi^{\prime} \alpha$ is the basis for other psychic benefits. For example, a man and a woman who often have sexual intercourse without love

12. Cf. 5.18-21, 5.43-54, 6.24-34; Beer 2009, p. 438, 479-482.

13. Lib. col. 1b and frr. 16, 42, 44; Mort. 4 col. 34.21-27 (ed. Henry 2009); Adul. col. 2.8-9 (ed. Gargiulo 1979); Vit. X col. 19.14-18 (ed. Ranocchia 2007). Philodemus also speaks of the purity of the gods, who abstain from adultery (D. III fr. 78; ed. Essler 2016). On this purification, see Gigante 1975, Koch 2005, p. 81-82, and Beer 2009, p. 420-435.

14. Incidentally, note that the evidence of the purification of cuppedinis acres (Lucretius, 5.43-46) confirms the interpretation that catharsis involves the checking of unlimited desires.

15. It is not strange to include love among the evil passions, since Epicureans regard it as a foolish and excessive craving for sex. See Brown 1987, p. 60-91 and 217-218, Nussbaum 1994, p. 140-191, Konstan 2007, p. 93-103.

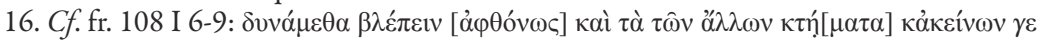

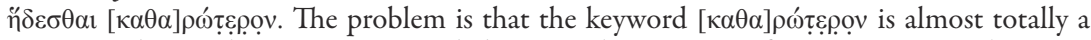
conjecture by Smith, so caution is needed. But on the existence of Epicurean "pure pleasures", cf. Epicurus. Sent. XII; Lucretius 3.40; Philodemus, D. III, fr. 1 (ed. Diels 1970) and Mort. 4, col. 15.36; Brown 1987, p. 220; Nussbaum 1994, p. 170-181.

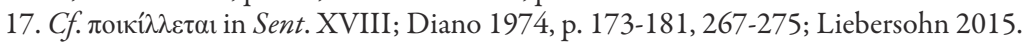


might develop affection for one another (4.1278-1287). In other words, they might establish a sort of friendly relationship that is added upon the pleasure of having a body without pain and a soul without irrational fears.

A final implication might be inferred from this third text on catharsis. Since pure katastematic pleasure represents a key feature of happiness, we could posit a connection between purification and well-being. Not only that, but since the process of cleansing passes through the rational means of teaching, we derive another element in support of the idea that the Epicureans regarded purification as a cognitive (i.e. not just passionate) experience.

We can now draw two conclusions. The positive one is that an Epicurean catharsis does indeed exist and constitutes an «intellectual clarification ${ }^{18}$. In the light of the previous analysis, it is plain that its objects are a wide range of emotions, which are either held in check (if they are excessive) or awakened (if they are deficient) by rational means, such as knowledge of the gods, rational evaluation of the phenomena, and teaching. The negative conclusion is that these same texts never link Epicurean catharsis with poetry or theatre. In truth, Epicurus' letter to Apelles and Philodemus' passages in the De pietate actually hint at a rejection of purification through theatrical or tragic performances which tell false stories about the gods. Since Epicureans think that human beings are cleansed by knowing the truth about the divine, these performances are not useful cathartic media.

Yet this negative conclusion does not imply the rejection of all poetical performances. It is still possible that those which do not express dangerous falsehoods about the divine might be cathartic. Nor does the negative conclusion imply that performances which tell false things about the gods will not result in purification for the whole public. The Epicureans knew that many of the things that were said/represented during the public rites in honor of the gods were not true, yet they took part in these rites all the same. Indeed, they participated by rejecting all the superstitious aspects and by concentrating during prayer on those contents which instead appeared pious or worthy of reflection ${ }^{19}$. So could it not be the case that they also watched performances which told false things about the gods, without paying attention to such impious beliefs but appreciating the potentially cathartic aspects of plays? Suppose, for example, that a theatrical piece presents philosophical teachings that help to limit desire, like Seneca's Thyestes $(393-403=$ fr. 551 Us.), thereby ensuring the kind of "cognitive" purification that is described in Sent.Vat.63. Would Epicureans accept this performance or not?

It is impossible to give a definite answer to these questions. Moreover, even if we accept that the Epicureans would have recognized a cathartic side to those performances that state the false about the divine, this would just

18. The point was already recognized by Golden 1992, p. 22 .

19. Details and texts in Piergiacomi 2017, p. 266-280. 
repeat the Epicurean idea that it is philosophy that leads to catharsis. It is the mind that reasons on the play and not the playper se that cleanses the souls of the audience. However, a solution might be gained from a comparison with the conception of tragic catharsis developed by Aristotle.

\section{Epicurus against Aristotle: toward non-cathartic performances}

Studying Aristotelian catharsis is a really difficult task. The main problem is that those treatises of Aristotle's that mention this process of purification do not explicitly state what it consists in, nor how it should be reached.

Let us then examine the evidence. The most important piece is Aristotle's Poetics. It suggests that catharsis involves the emotions of fear and pity (and possibly also of passions similar to these $\mathrm{e}^{20}$ ), through a specific mimetic act. Tragedy imitates human beings who are similar (yet in part superior)

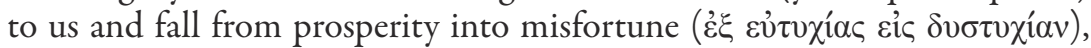
for an error committed involuntarily, namely innocently and without evil intentions. Indeed, it is this kind of plot that produces responses of pity and fear. Other plots - such as that of the reasonable or '̇лıєкńc individual who falls into misfortune, or that of the evil man who achieves prosperity / $\delta v \sigma \tau u \chi i ́ \alpha-$ may elicit intense responses, but not those which we call "tragic". Pity comes at the sight of people who are innocent and suffer undeserved disgrace, fear when we realize that what happened to these characters could be our own fate, given the similarity between them and $\mathrm{us}^{21}$. The experience of all this catharsis is a pain mixed with pleasure. Pity and fear are themselves painful, but if we feel them during tragic performances we somehow derive the "proper pleasure" of tragedy ${ }^{22}$. Finally, it should be added that tragic catharsis seems to be in principle an experience which could be had both with and without music / actors. Aristotle clearly says, after all, that the latter elements of tragedy are surely important means of purification and stand out for their efficacy on stage, but that the tragic plot alone is what determines

20. $C f .1449 \mathrm{~b} 24-28$. In this same passage, Aristotle writes that through pity and fear

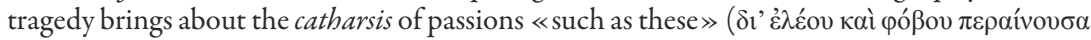

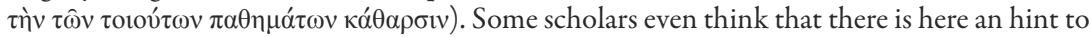
cathartic comedy. See Untersteiner 1955, p. 102-105; Janko 1984, p. 82-83, 143-147; Belfiore 1992, p. 268-270, 354-358; Sorabji 2000, p. 290-292 ; Fortenbaugh 2002, p. 19-22; Fortenbaugh 2005, p. 373-374; Rapp 2009, p. 90. Contra Leighton 2003.

21. Cf. 1452b28-1453a17. On the status of Aristotle's tragic character and tragic emotions, see Reeves 1952; Adkins 1966; Stinton 1975,p. 239-244; Østerud 1976, p. 67-74; Lear 1992, p. 330-331; Lear 1995; Nussbaum 1992, p. 134-136; Nussbaum 2001, p. 381-383, 387-388; Belfiore 1992, p. 83-110; Sherman 1992; Konstan 2001, p. 59-60; Konstan 2005; Guastini 2010, p. 249-262; Kim 2010, p. 38-43; Bouchard 2012, p. 185-190; Frazier 2012, p. 111-121; Heath 2013 p. 83-95. Contra Sorabji 1980, p. 295-298. Cf. also the similar perspective of Theophrastus, according to whom tragedy is a crisis of heroic fortune (fr. 708 FHS\&G, with at least Fortenbaugh 2005 p. 355-374).

22. Cf. 1448b4-24, 1459a17-24, Belfiore 1985; Rapp 2009, p. 93-97 ; Destrée 2012. 
catharsis, independently of its representations ${ }^{23}$.

The picture that emerges from what we read in the Poetics mostly agrees with book VIII of Aristotle's Politics ${ }^{24}$. This text presents catharsis as a process which reduces pity, fear and also many other passions, and that also gives pleasure by mimetic means. It attributes a cathartic power to melodies, because they imitate moral characters (e.g. the angry one, the pitiful one, etc.), so the listeners can experience with them the corresponding emotion in a controllable (and hence purifying) way ${ }^{25}$. It is true that Politics VIII recognizes that music is a direct and essential means for catharsis, and thereby diverges from a key point that we have found in the Poetics: that music is only a part of the performance and one that, like the actors, is useful but not really necessary for catharsis. But I think the contradiction is only an apparent one, if we recall that Politics VIII is mainly focused on the use of melodies for the education of young, imperfect and uneducated people, which is to say human beings who do not yet have access to theatrical performances ${ }^{26}$. By keeping this in mind, we could suppose that Aristotle is not describing the music that is employed in theatre, as is proved by the fact that he only incidentally mentions it in passage 1342a15-18. Contradiction is avoided, therefore, because the Politics consider music an independent source of catharsis for the young who are forbidden to attend the theatre, while the Poetics is describing a performance for adults.

These are the points which are not (too) controversial. There are instead two problems of some importance that still lack scholarly consensus. The first is: what is the subject of Aristotelian catharsis? Although the majority of scholars suppose that it should be identified with the audience, some interpreters suggest that it can also be identified with the actors, or even with the characters of the play ${ }^{27}$. The second much more debated problem is how the connection between tragic/musical mimesis and catharsis must be interpreted. Among the many interpretations suggested, I might mention:

23. I follow the interpretation that Marino 1999, p. 22-29, and Guastini 2010, p. 189-190, 267-268 and 364-367, give to passages 1450b15-20, 1453b1-11, 1462a5-b15.

24. Pol. VIII, 1339b40-1340b136; 1341b32-1342a18. Janko 2011 thinks that these passages are frr. 53-54 of Aristotle's lost treatise On Poets. Other possible fragments might be the passages of Iamblichus, Myst. I 11 and Proclus, In Remp. vol. I, p. 42 and 49-50 Kroll (= frr. 55-56). Mind, however, that Aristotle and the two Neoplatonic philosophers never say that they are presenting the contents of the treatise On Poets.

25. This belief will be shared by other Peripatetics, for example Theophrastus (frr. 716 and 726a-c FHS\&G), as well as Aristoxenus (frr. 6, 26, 122-123, ed. Wehrli 1967) and Chamaleon (frr. 7-8, ed. Matelli 2012).

26. Cf. the parallel provided by Pol. VII 1336b13-17. See Lear 1992, p. 316-318; Jones 2012; Heath 2013, p. 94-95, 99-103. On the imperfection of young people, see Fortenbaugh 2002, p. 49-53; Ford 2004 p. 328; Donini 2004, p. 80.

27. Cf. respectively Watson 1988 and Else 1986, p. 158-162. 
1. the therapeutic one - humans are ill, because fear and pity are present in excess or defect in souls, so tragedy must purge them ${ }^{28}$;

2. the hedonistic one - tragedy gives aesthetic pleasure which one seeks for its own sake ${ }^{29}$;

3. the cognitive one - purification is a sort of induction of the universals, or re-interpretation of reality and of ourselves, hence an epistemological tool ${ }^{30}$;

4. the ethical one - cleansing pity and fear leads to virtue ${ }^{31}$.

Other scholars, however, reject these hypotheses. Some argue that the passage itself on catharsis is an interpolation, therefore that it must be suppressed or corrected ${ }^{32}$. Others affirm, instead, that the text may just be a reference to the proper conclusion of a tragic plot $^{33}$.

It is of course impossible to reassess here the whole topic, even less to solve a question which has yet to receive a definite assessment after centuries of debate between philosophers, philologists and the like. Fortunately, since my focus on Aristotle is intended to be a means to better understand Epicurus' possible conception of catharsis, I can skip all these problems of detail and just focus on the Epicurean interpretation of the theory.

If PHerc. 1581 is a surviving extract of book V of Philodemus' On Poems and a conscious attack on the Peripatetic cathartic theory ${ }^{34}$, we have evidence that Epicureans may have challenged the idea that the subject of catharsis consists in the audience and expressed the ethical interpretation. The opening fragments ( 1 and 2 ) of the text attribute to catharsis the power to purify human beings by eliminating those character flaws that remain even in

28. This interpretation goes back to Bernays 1857, on which $c f$. Ugolini 2012, p. 15-108. Cf. more recently e.g. Koller 1954, p. 73-74, 111; Cooper 1956, p. 30-32; Else 1986, p. 159-161; Flashar 1956; Sorabji 2000, p. 288-293.

29. Cf. e.g. Schaper 1968; Oksenberg Rorty 1992b, p. 14-16.

30. See for example Untersteiner 1955, p. 110-114; Pesce 1981, p. 25-26, 32; Golden 1992, p. 25-39; Lear 1992, p. 331-335; Belfiore 1992, p. 335-358; Nussbaum 2001, p. 389-394; Saintillan 2003; Tsitsiridis 2005; Halliwell 2011, p. 254-259; McCoy 2013, p. 187 , p. $199-200$.

31. See Janko 1992; Heath 2003; Heath 2013, p. 94, 99; Guastini 1999, p. 280-283; Guastini 2003, p. 108-122; Guastini 2010, p. 164-168; Donini 2004, p. 53-66; Donini 2008, p. 356-357; Palumbo 2008, p. 508-510; Rapp 2009, p. 101-103.

32. See Scott 2003; Veloso 2007; Rashed 2016. Contra Halliwell 2011, p. 260-265.

33. Like Anton 1986, and Nehamas 1992, p. 303-308.

34. Edition of Nardelli 1978, now reedited by Janko 2011 p. 446-451. The latter scholar also believes that these fragments are the remains of books I-II of Aristotle's On Poets ( $=$ frr. 45-52b) and that Philodemus is attacking this treatise (Janko 2011, p. 372-378). Gigante 1993, p. 132, Gigante 1999, p. 74-79, Rispoli 2005, p. 211-218, and Rispoli 2012, p. 264 suppose a polemic with the Poetics, Hammerstaedt 1997, p. 117, one with a later Peripatetic. Doubts are voiced by Brink 1972. More generally, on the debate between Kepos and Peripatos, see Jannone 1996; Gigante 1999 passim; Pace 2009, p. 262-263. 
the souls of the best individuals and by leading the latter to a virtuous state. The later fragments (frr. 3-6) may instead be further presenting the Peripatetic view, while rebutting it. Unfortunately, the text is really fragmentary and, therefore, many details remain obscure. It seems, however, that Philodemus' discussion attacks the conception of tragic error ${ }^{35}$, the catharsis of

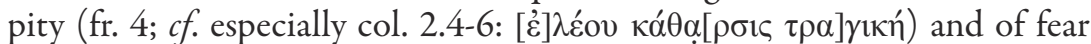
(fr. 5), and the benefits of the arts in general (fr. 6). At the very least, we have hints of the fact that, for an Epicurean, there was something wrong with the Peripatetic treatment of all these points. What was specifically wrong is a detail that PHerc. 1581 omits.

Is there a way of filling these gaps? I believe that the answer is affirmative, because certain Epicurean texts suggest what kind of criticism Philodemus could have directed against Aristotle. In the following pages, I will suppose that this criticism concerned at least four points: 1) the Peripatetic tragic plot is not cathartic; 2 ) it is false to state that all human beings require poetic catharsis; 3) music and actors do not aid the cleansing process; 4) it is pointless to try and reduce fear and pity to a mean.

\section{1. «The Peripatetic tragic plot is not cathartic.»}

We have seen that according to Aristotle the tragic emotions arise with a specific kind of plot: the story of the superior individual who falls

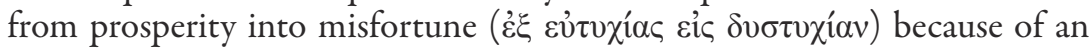
involuntary error. We have also seen that this outcome elicits pity, because the character in question suffers an evil without being at fault, and fear, because we suddenly discover that what happened to him or her could actually befall us as well. What did Epicureans make of this dramatic structure?

A direct answer is prevented by the lack of evidence. Epicurus and Metrodorus ${ }^{36}$ would have invited others to avoid engaging in literary theory, since this activity does not reward one with pleasure. Only Philodemus seems to have faced the problem of the structure of plots in his treatise On Poems, for example in the passages of book IV that object that Aristotle's indications about perfect plots are questionable, or in the section of book V, where he notices that the kind of plot full of ideas, twists, and misadventures is capable of producing responses of pity ${ }^{37}$. Even here, however, the Epicurean only

35. Frr. 3-3bis. It is not clear whether the "tragic error" attacked here is to be interpreted as the error of the characters of the play, as the error of the poets who devised the plots (Rispoli 2012 p. 267), or as both (Janko 2011 p. 515, 521-522).

36. Plutarchus, Suav. viv. 1094E1-1095D1 = Epicurus, Frr.[9, 12.2], Metrodorus, fr. 24 (Körte 1890).

37. Cf. Po. 4, coll. 110.3-112.17 (ed. Janko 2011), Po. 5, coll. 34.33-37.2 (ed. Mangoni 1993), with Greenberg 1990 p. 125-129. Arrighetti 2011 p. 74-82 finds other points of criticism that Philodemus directed (often indirectly) against Aristotle, including the interesting one that the poet might write poetry without mimesis. 
evaluates the poetic theory of his adversaries. Philodemus' own ideas of how plots should be constructed are unknown to us.

But there is one thing that allows us to suppose that the Epicureans were critical of Aristotle's tragic plot. It is the idea that this change of fortune is something that one should actually pity and fear. To prove my case, it is necessary to briefly recall the contrasting conceptions of the relationship

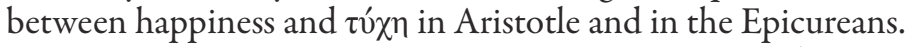

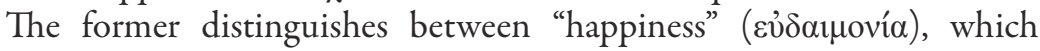
consists in the ability to practice virtue even in difficult circumstances, and

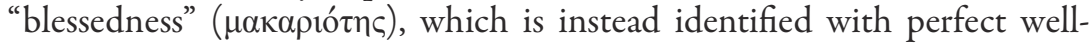
being: the possession of both $\alpha \rho \varepsilon \tau \eta$ and some external goods granted by fortune $^{38}$. This point allows us to infer that, when Aristotle speaks of the

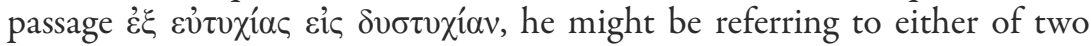
scenarios. He might be alluding to a passage from blessedness to happiness, if the change of fortune is only partially harmful, gradual and allows the practice of virtue, or to unhappiness, if the reversals of fortune are so sudden, numerous and radical as to preclude any virtuous conduct. I believe that, at least in relation to tragedy, what Aristotle is describing is the latter scenario. Tragic characters are like the Priam of book I of the Nicomachean Ethics (1100a5-9, 1101a6-21), who loses all his wealth, offspring and power in a brief period of time and cannot hope to recover from his disgrace. In this sense, the pity and fear which we feel when we contemplate the misfortunes of those who are similar yet superior to us are true or rationally grounded emotional responses. In turn, these could constitute the proper means to achieve a beneficial catharsis.

Things change drastically when we consider the Epicureans. These philosophers staunchly believed that blessedness is not based or influenced by fortune, for the latter is something that can be controlled or at the very least endured by wise human beings. For example, $\$ \$ 134-135$ of Epicurus' Epistle to Menoeceus state that fortune is not the cause of good and evil, but only of the principles of good and evil. I interpret this affirmation as the assertion that bad reversals of luck - even those that are sudden and radical - are not an evil per se and that good reversals of luck are not beneficial per se, but that the former are harmful when the individual is not trained to overcome its difficulties and the latter ones are beneficial when a person is capable of exploiting the situation for his own gain ${ }^{39}$. On the other hand, the text

38. Cf. EN I 1120b22-1121a8; Cicero, Tusc. V 30.85-31.87 (= fr. 998 Gigon). On the topic, see Bignone 1973 vol. 1, p. 143-145; Pesce 1981, p. 19-20; Heinaman 1985; Scott 2000, p. 212-216; Nussbaum 2001, p. 318-372; Verde 2013a. Theophrastus thought the same as his master (cf. e.g. fr. 493 FHS\&G = Cicero Tusc. V 9.24-25).

39. On the immunity of wise human beings from fortune, $c f$. also Diogenes Laertius, X 120a; Epicurus, Sent. XVI, fr. 489 Us. (= Porphyrius, Marc. 30); Philodemus, Div. I, col. 
reports that it is better to suffer an unfortunate fate while being wise, than to enjoy a fortunate one while being a fool. The wise man is able to endure these difficult situations and to wait with confidence for another reversal of fortune. Alternatively, if this hope proves impossible owing to sudden and radical twists of fate, he could take refuge in the remembrance of past goods and even commit rational suicide ${ }^{40}$. Foolishness will instead eventually lead to doom and makes one incapable of enduring changes for the worse.

So an Epicurean would find it difficult to follow Aristotle's plot and to regard it as rationally cathartic. If the tragic individual is really similar yet superior to us, i.e. if he or she is more virtuous and wise, his or her change of fortune must not appear pitiable and fearful ${ }^{14}$. He or she would have to be represented as blessed even in extreme situations.

\section{2. «It is false to state that all human beings require poetic catharsis.»}

We have seen that Aristotle thinks that all human beings require catharsis, for everyone (including the best souls) has traces of vice which must be purified and transformed into virtue. The point is clearly explicated in book VIII of the Politics (1342a11-16) and Philodemus recognized this aspect correctly in fr. 2 of PHerc. 1581:

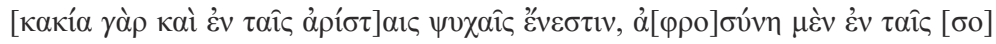

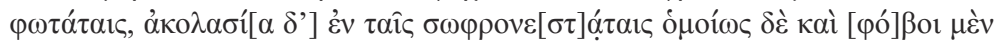

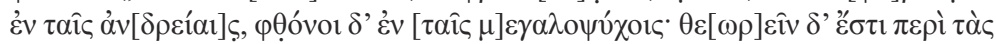

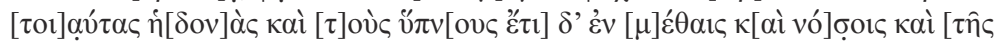

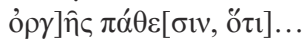

(For) there is (vice even) in (the best) souls, folly in the wisest, lack of selfcontrol in the most prudent. Likewise there are fears in brave souls, and jealousies in magnanimous ones. One can observe regarding such pleasures and dreams, and again in drunken states, illnesses, and outbursts of anger, (that) (breaks off)... (trans. Janko 2011 p. 447.)

Would the Epicureans have agreed with such a perspective? Apparently, the answer is positive. Epicurus thinks that human beings are weak by nature, meaning that they are naturally prone to emotions like pain, fear, and solitude (Epicurus, Ep.Her. 77; Sent. I). Some of these passions cannot be avoided even by wise human beings, who are susceptible to at least four

36 (ed. Tepedino Guerra 1978); Philodemus, Mort. 4, coll. 37.18-39.25; Bignone 1973 (vol. 1, p. 370-373; vol. 2, p. 96-102); Konstan 2007, p. 162-163; Verde 2013b; Mitsis 2014, p. $195-200$.

40. I provide some arguments and texts in $\$ 2.4$.

41. More generally, Epicurus invites us not to fear fortune and its constant changes. Cf. Ep.Men. 131 and the fragment quoted in Philodemus, Div. I, col. 36.9-14. Mind, however, that the plot described in this Epicurean criticism is exactly identical with Aristotle's plot of

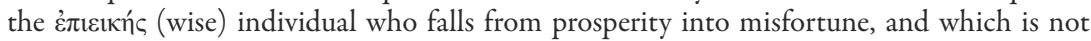
regarded as tragic and therefore, cathartic (1454b34-36). But $c f$. here Stinton 1975, p. 226. 
of the items listed at the end of fr. 2 of PHerc. 1581: the fear provoked by nightmares, illness, anger, and drunkenness ${ }^{42}$. In this sense, it seems that an Epicurean would agree that all human beings require some kind of catharsis.

However, if we were to ask ourselves whether Epicurus and his followers also thought that the catharsis described by Aristotle is what is really needed to cleanse humans from vicious passions, we would have to answer: no. We have already collected the evidence in $\$ 1$ that shows that evaluation and teaching already purify minds from love, the excess or deficiency of desire, folly, fear, envy, and so on, i.e. from almost all the evil passions reported in fr. 2 of PHerc. 1581. Now it is time to add that these rational procedures almost completely remove vicious and harmful traces from the whole human being. Lucretius explicitly states that ratio is so powerful that it removes all the vestigia of vice that prevent us from leading a life worthy of gods (3.315322). As regards the emotions that even the Epicurean wise humans feel, it is sufficient to note, on the one hand, that their rational abilities are so developed that they will never be disturbed by their nightmares (their sleep is, after all, as calm as their waking life) and will moderate excessive anger by transforming it into a means to pleasure ${ }^{43}$. On the other hand, those who have wisdom will endure illnesses (Epicurus, Fr.[52] = Diogenes Laertius, $X$ 22) and will never experience drunkenness, but just become moderately tipsy ${ }^{44}$; hence, they are not prone to the immoral behavior that normal human beings display while ill and drunk. The wise human beings have become so reasonable that they are immune from those negative emotions, even if they still experience them. Therefore, they do not require the poetic catharsis described by Aristotle.

What I have argued is sufficient to prove that Epicurus and his followers may have attacked Aristotle's belief that all human beings require poetic catharsis in order to become virtuous. Wise individuals are the great exception that shows that this poetry is useless at least for some people. Partial proof of this is Colotes' criticism of Plato's myth of Er (ap. Proclus, In $R$. vol. II, p. 106.9-14 Kroll), as well as Diogenes of Oenoanda's criticism of the tales of the underworld and of gods who punish evil men as an instrumentum regni $i^{45}$. Both Epicureans show that wise human beings cannot be induced to behave better (e.g. to be just and to despise death) by these poetic devices, and hence that the latter are not a means to improve their character.

42. Cf. Diogenes Laertius, X 15 and 22; Philodemus, D. III, col. 12.1-14 (ed. Arrighetti 1961), Ir. coll. 43.14-41, 46.40-48.24 (ed. Indelli 1988).

43. Diogenes Laertius, X 121b; Epicurus, Ep.Men. 135; Philodemus, Ir. coll. 37.39-40.41

44. Cf. Diogenes Laertius, X 119 and 121b; Epicurus, Ep.Men. 135; Philodemus, Ir. coll. 34.35-38.34, 48.38-49.26, with Indelli 1988, p. 212-222, 245-246; Tsouna 2003; Delattre 2009, p. 83-85. .

45. I am quoting coll. 3.1-7.13 of the "theological-physical" fragment now edited by Hammerstaedt-Smith 2014, p. 263-265. On its content see at least Pace 2005. 
But are those who possess wisdom the only ones for whom poetic catharsis proves useless? I believe that an Epicurean would have added also utterly foolish people to the list. The already quoted texts by Colotes and Diogenes of Oenoanda report that, just as the poetic devices of Plato's myth of Er and the tales about the underworld and punishing gods are useless for the wise, so these devices have no effect on fools, albeit for different reasons. While the former individuals do not need poetry to behave better, the latter's behavior cannot be changed simply by means of it. The educational value of Plato's myth of Er is not understood by fools, while the tales of the instrumentum regni will at best prevent them from committing acts of injustice for a short time, but in the long run will lose all power over them.

There remains a third possibility. Poetic catharsis may be useful for those who are neither wise nor foolish. Common sense (and maybe Aristotle) would actually accept this perspective, because it seems plain that there are few wise men and fools. The problem with this hypothesis is that evidence shows that for the Epicureans there are no individuals who are neither wise nor foolish. Torquatus (ap. Cicero, Fin. I 17.57-19.62), Velleius (ap. Cicero, ND I 9.23) and Lucretius (e.g. 2.1-61, 3.31-93, 6.1-41) sharply divide humanity into wise and fools, while recognizing that the latter represent the majority ${ }^{46}$. The Epicureans, in this respect, go against common sense. If you are not one of the few exceptional wise men, then you are just one of the countless unhappy fools who have not been enlightened by Epicurus' teaching.

\section{3. «Music and actors do not aid the cleansing process»}

The hypothesis that Aristotle's tragic plot is not conducive toward catharsis represents a harsh criticism. But the Epicureans also have good reasons to attack his idea that music and actors - though not necessary can aid the cleansing of pity, of fear and of other disturbing emotions. Our evidence shows that this perspective was in all likelihood rejected by the Epicureans for psychological reasons.

46. It could be objected that Seneca alludes to the existence of persons who are neither wise nor fools, when he refers to Epicurus' belief that those who do not reach the truth of Epicureanism (= wisdom) by themselves are individuals either like Metrodorus, who spontaneously followed the path to wisdom paved by his master, or like Hermarchus, who instead needed assistance and even coercion (Ep. 52.3 = Epicurus, fr. 192 Us.; Metrodorus, fr. 30 ed. Körte 1890; Hermarchus, fr. 18 ed. Longo Auricchio 1988). This inference is possible, but not necessary. It could still be said that, before becoming wise and attaining the truth, Metrodorus and Hermarchus were foolish. The same principle can be applied to the attack delivered by the Epicurean Diogenianus against Chrysippus' use of common beliefs for demonstrating that fate exists ( $c f$. Eusebius, PE VI 8.9-17 = Diogenianus, fr. 2 ed. Gercke 1885; SVF III 324, 668, 914). It is true that the former objects to the latter that this method is inconsistent, because it puts trust in the majority of humankind, who the Stoics considered foolish. Nonetheless, Diogenianus does not conclude for this reason that the distinction between wise individuals and fools is false or absurd. 
The perspective of Aristotle's Poetics that music imitates moral character and induces souls to an appropriate emotional response is challenged by Philodemus. He attacks, after all, the similar view held by Diogenes of Babylon, according to whom music imitates character and arouses in the hearer the same passions as melodies elicit, for example pity ${ }^{47}$. And while we have no evidence that this criticism was also raised against Aristotle's Politics, the hypothesis is not disproved by any other Epicurean text.

The thesis that actors can aid catharsis could be criticized instead by noting that the Epicureans have a different conception of the performers. It is true that the former disagree with Aristotle's claim that the latter represent a dispensable part of tragedy. Epicureans believe, after all, that a mimetic performance can lack music, as is shown by those mimes which are staged without musical accompaniment, but that it cannot lack actors, due to their psychagogic force ${ }^{48}$. These philosophers would not agree, however, that acting consists in making the audience feel some painful passions, like fear and pity. An interesting evidence is provided by passage 673C4-D7 of book V of Plutarch's Table Talks. The text attributes to the Epicurean Boethus and his friends the belief that, if we feel pleasure by contemplating actors who imitate angry, grieved and fearful characters, it is not because we bring to a mean the passions of anger, grief and fear. On the contrary, we derive delight from the understanding that we are immune from the passions that are being represented on stage ${ }^{49}$. Lucretius relates something similar in book II of the De rerum natura (vv. 1-13), where we read that it is this very sense of immunity that makes the Epicurean observer delight in the sight of the anguish of non-Epicureans ${ }^{50}$. There is of course also a difference compared to Boethus. While the latter derives delight from actors that pretend to suffer, Lucretius experiences delight by looking at human beings who are really suffering. The logic of the explanation, however, remains the same.

Unfortunately, Boethus' conception is not connected to the topic of tragic catharsis. Therefore, we should be aware of the fact that its application to the latter theme is speculative and doubtful. The Epicurean might simply wish to distinguish aesthetic or mimetic experiences from ordinary ones, in a way

47. Mus.4, coll. 90.34-91.12, 136.27-137.2, 147.1-6 (ed. Delattre 2007) = SVF III 63.

48. Demetrius Lacon, Po. 2, col. 27.3-9 (ed. Romeo 1988); Philodemus, Po. 4, coll. 107, 109, 113, 119.11-19; Gigante 1993, p. 133-134; Rispoli 2012, p. 243-245, 261-262.

49. On the topic, see also Warren 2013, Verde 2015, p. 210-211. Incidentally, I would like to note that the Epicureans believe that poets do not seek to be coherent and to attribute to their characters a behavior which fully expresses the conduct of real human beings. At least, this was the opinion of Diogenianus (fr. 1 = Eusebius, PE VI 8.7, ed. Gercke 1885).

50. Cf. especially verses 4 (sed quibus ipse malis careas quia cernere suave est), 6 (sine parte pericli), 7-8 (bene quam munita tenere / edita doctrina sapientum templa serena). 
reminiscent of Aristotle ${ }^{51}$. What is more, Boethus reports this doctrine in his reflection on comedy. However, given that both Aristotle and the Epicureans do not question the premise that tragedy is a form of mimesis, it is possible to claim that the latter affirm that tragic actors cannot induce pitiful and fearful reactions, because the spectators know that they are getting a taste of passions that they are not actually experiencing themselves.

It is possible to infer from this third objection that music and acting do not aid the cleansing of the passions. They may offer just a natural but non-necessary pleasure. This supposition finds direct confirmation when music or poetry is concerned ${ }^{52}$. As regards actors, the qualifying of the pleasure that they grant as natural and non-necessary is not explicit. Diogenes of Oenoanda says, however, that theatrical performances are not like the science of nature (fr. 2 III, 4-14), which removes fear/turmoil and brings katastematic pleasure, thereby satisfying a natural/necessary desire for happiness. The contrast might be taken to suggest that the pleasure of attending shows must be included among the natural and non-necessary tendencies ${ }^{53}$. If so, it follows that actors offer pleasures which vary the pleasurable peace of the soul, but do not add something relevant to our personal well-being.

\section{4. «It is pointless to try and reduce fear and pity to a mean»}

The three previous objections may be valid, but they do not attack catharsis directly. Rather, they concentrate on issues with which the latter is connected (the relationship between misfortune and happiness, the anthropology of the passions, the efficacy of music and actors as a means in tragedy). The fourth objection which I would now like to reconstruct differs from the preceding ones, however, because it attacks catharsis at its very core. The Epicureans interpreted the cathartic theory of Aristotle as the power to reduce fear and pity to a virtuous mean. Now, did these philosophers consider this the proper goal of philosophical activity?

In order to answer this question, it is necessary to recall why Aristotle thinks that it is good to reduce fear and pity to a middle state, and what the implications of this are in his view. Both the Poetics and book VIII of the

51. This philosopher already noted that things that normally disturb us become pleasurable when they are imitated (Po. 1448b4-19). The difference between Aristotle and Boethus concerns the focus of their explanation. Aristotle invokes a cognitive process: imitations of ugly objects (say, corpses) are pleasurable because the audience recognizes the representational significance of these copies ("this thing here is a corpse": cf. Halliwell 2002 p. 181-191). Boethus instead invokes a moral reason: we feel pleasure because we feel a sort of superiority toward the character who is being represented.

52. Cf. e.g. Philodemus, Po.1, coll. 160.19-20, 208.16 (ed. Janko 2000), Mus.4, col. 78.2931, with Koller 1954, p. 152-157; Delattre-Delattre 1994, p. 170-171; Konstan 2005, p. 16; Rispoli 2005, p. 195; Rispoli 2012, p. 270; Heath 2013, p. 111-113.

53. Cf. for other confirmation Giancotti 1977, p. 26-29, p. 500-507. 
Politics do not explain all these points. We need to turn to other texts.

Fear and its relation to the virtue of courage is studied in EN III, $1115 \mathrm{a}-1117 \mathrm{~b} 22^{54}$. The important point which interests us here is that according to Aristotle virtuous or courageous conduct consists in the virtuous middle between cowardice (i.e. fleeing in terror in the face of just about everything) and fearlessness (i.e. facing without fear even those things which should be rationally feared). Courage, then, is not coupled with the absence of yóßoc. It consists in facing and fearing right things with the right aim, in the right way and at the right time (cf. 1115b10-24, 1116a10-15, 1117 a15-20). The most terrible evil which has to be endured with courage is death in battle (1115a28-b6). Wise and courageous individuals will painfully fear their destruction, because they know that, if they will be killed, they will lose all the good things in life that their virtue allows them to recognize and appreciate (1116b19-23, 1117b5-15). In other words, in relation to death courage does not consist in accepting the risk of dying without fear. It means facing dissolution with the inevitable pain of knowing that, if we die, our personal goods will be lost, while also recognizing (this time with fearlessness) that we are performing a morally beautiful act: we die for the higher good of our city or community ${ }^{55}$. It has to be noted, incidentally, that such a conception of courage allows the philosopher to claim that courage is neither accompanied by pleasure, nor a means to this goal, because the courageous individual does indeed act with virtue while suffering (1117a34b19).

Things get more tricky when it comes to pity. Nowhere does Aristotle describe the relation of this passion to its virtuous mean, which he believed was achievable ( $c f$. indeed $E N$ III, 1106b18-27). The extensive account of pity presented in book II of the Rhetoric (1385b11-1387a5) never mentions virtue and describes instead who should feel हैं $\lambda \varepsilon o \varsigma$, when and how, while also distinguishing it from scorn and envy. So on this topic it is possible only to offer highly speculative hypotheses ${ }^{56}$. I believe that the most promising ones are those that try to take more into account the only other passage where Aristotle explicitly links virtue and pity. I am referring to EN III, 1109b3035 , where the philosopher states that those who wish to study virtue must

54. Cf. also the similar but slightly different account of $E E$ III, 1229b13-1230a8.

55. On this aspect, see especially Pears 1978, p. 277-282; Deslauriers 2003, p. 188-192. Aristotle's account of courage has appeared contradictory to some interpreters, or prone to attributing to the courageous individual a sort of conflict between the fearless desire for the beautiful and the painful/fearful recognition that death will destroy all goods (e.g. Pears 1980 p. 186). But see Rogers 1994, p. 306-311, Heil 1996, p. 58-68, and Brady 2005, p. 190-204, for persuasive explanations of why there are not necessarily contradictions and inconsistencies in the Aristotelian scheme.

56. See e.g. Nussbaum 1992, p. 149-150; Konstan 2001, p. 126, 128-136; Crisp 2008, p. 240-245. 
understand that voluntary actions require praise or blame and that involuntary ones require forgiveness or pity ${ }^{57}$. Although Aristotle does not state it explicitly, I suppose that this conception implies the idea that some actions are virtuously and rightly pitied as involuntary, while others are wrongly pitied. Possible confirmation is to be found in the long passage that follows soon afterward (1110b18-1111a21). Aristotle claims here that the actions which deserve pity and forgiveness are not those performed by people who ignore what must be done or avoided (e.g. who ignore that parricide must be avoided), for this is perversity, nor those actions performed in ignorance of universal principles (e.g. ignoring that parricide is always bad), for these are worthy of blame. Rather, only those actions that ignore the particular (e.g. when I ignore that the man I am taking to be my enemy and killing is, in reality, my father) deserve pity and forgiveness: for only these are involuntary in the proper sense ${ }^{58}$. If that is so, we could suppose that the virtuous middle in pity consists in avoiding both the defect of pitying no one, for example by blaming he who does not recognize his father, and the excess of pitying everyone, as happens when one pities even the evil man who is not aware of how terrible parricide is. Of course, this must remain an hypothesis, due to the absence of direct textual confirmation, which leaves the relationship between pity and virtue obscure.

Bearing all this in mind, let us return to catharsis. If we follow the ethical interpretation, we could say that the fearful and pitiable representations of

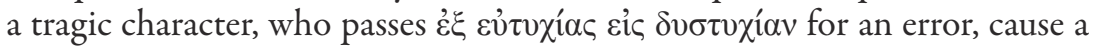
cathartic process and lead to virtue, because they lead us to feel a virtuous fear and pity. Let us consider what is arguably the piece that best describes the typical Aristotelian plot: Sophocles' Oedipus King. The spectators witness that, in one day, Oedipus discovers that in the past he killed his father involuntarily (e.g. having failed to recognize him), and suddenly loses his reign, his mother (whom he has involuntarily taken as his bride), his sight and all the goods that he has been enjoying. Now, according to Aristotle, by interpreting the play ethically, those who have a distorted/corrupt perception of pity will sympathize with the tragic character and will be brought to a middle state. Indeed, those who are in defect of ह̌n $20 \varsigma$ will avoid blaming Oedipus, because his misfortune was caused by involuntary parricide, while those who suffer an excess of it and are prone to forgive everyone will find

57. This was already recognized by Nussbaum 1992 p. 136. The two dispositions may differ for the following reason: pity is the outcome of a mistake, namely something involun-

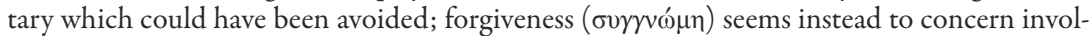
untary actions which arise from causes which are not under the control of our nature (EE II, 1224b19-22; EN III, 1136a1-10 and VII 1145b27-1146a9). On the different emotional responses toward the misfortunes of others, see now Ben-Ze'ev 2003.

58. More detailed arguments are furnished by Glanville 1949; Stinton 1975, p. 228-235; Sorabji 1980, p. 259-281; Else 1986, p. 148-150; Kim 2010, p. 46-50. 
a better equilibrium. Oedipus could have avoided killing his father at the crossroads, so he is not entirely to be pitied: he is still guilty of homicide ${ }^{59}$. Conversely, the same happens in relation to fear. Oedipus' fate cleanses the audience because, on the one hand, it challenges the confidence of those who think that they are indestructible and therefore dread nothing, since the character is a little superior yet still similar to them while, on the other hand, it may induce the more cowardly spectators to take courage. After all, the protagonist of Sophocles' play does not cowardly avoid his misfortune, which in Aristotle's view would be a vice induced by fear of pain (EN III, 1116a10-15). Oedipus goes voluntarily into exile and endures his ill fate: that is the morally beautiful act that he can still practice after the disaster. In short, we could suppose that catharsis purifies: 1) fear by letting the audience become fearfully aware of the fragility of human goodness and acquire the courage to struggle for moral beauty even in misfortune; 2) pity by inducing the audience not to blame those who are not entirely responsible for their errors and not to fully forgive those who are guilty of something that they could correct/avoid.

Providing that this more detailed presentation of Aristotle's theory of tragedy is sound, we could take one final step to show that the Epicureans would have considered it pointless to try and reduce these two passions to a mean. Firstly, they would have objected that fear must not be tempered, but completely removed from the soul: after all, $\alpha \tau \alpha \rho \alpha \xi i \alpha$ is conceived as the total removal of turmoil (Epicurus, Ep.Men. 128). My point could be demonstrated by contrasting Torquatus' description of courage ( $a p$. Cicero, Fin. I, 15.49) with Aristotle's one. The Epicurean does not think that fear must be moderately present in the courageous individual. On the contrary, courage is identified with the absence of worry, of dread and - as far as this is possible - of any source of sufferance. Unlike Aristotle's courageous individual, then, Epicurus' wise man or woman despises death and does not fear it as the most terrible of all evils or as a threat to our happiness ${ }^{60}$. He or she tries to remove pain in all its forms, and not to masochistically endure it. Finally, he or she will choose to relinquish his or her life with serenity, if the sources of disturbances are no longer endurable. With this description, Torquatus challenges Aristotle's interpretation of courage as a virtue which as we have seen in EN III, 1117a34-b19 - does not have pleasure as its proper

59. Cf. Sherman 1992, p. 189: «Oedipus acts out of an ignorance that is stultifying. There is little he contributed to bring it on, and little he could have done at crucial moments to come to an earlier recognition». For the argument that this would have been the belief of Aristotle and Peripatetics like Alexander of Aphrodisias, see Pack 1937, p. 434-436; Cooper 1956, p. 82-83; Else 1986, p. 150-151.

60. On this much debated topic, see at the very least Warren 2004 p. 17-56, 109-160; Tsouna 2007, p. 239-311; Alberti 2008, p. 188-190; Mitsis 2014, p. 23-49; . 


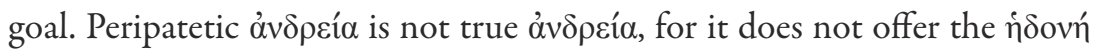
that all virtuous behavior must provide (Epicurus, Ep.Men. 132). It follows that showing Oedipus' fate is not cathartic, if Epicurean catharsis entails the removal of all fear, or at least all those forms of negative and irrational fears that do not lead to some indirect benefits ${ }^{61}$. This tragic character would have been courageous if he had either tried to find pleasure after his fall, for example by remembering with gratitude the past goods he had enjoyed in his previous life ${ }^{62}$, or by committing rational suicide, if the circumstances ruled out even the experience of the past pleasures stored within his mind.

Secondly, the Epicureans might have been less inclined to attribute all this importance to pity and, therefore, to the aim of reaching a cathartic mean. As in Aristotle's case, however, caution is needed due to the lack of any evidence of a link between this passion and virtue. What can be said with certainty is that pity is rightfully shown toward those who are suffering or facing misfortune. This list includes slaves, old men who did not experience anything good in their lives, wretched individuals, those who lack heirs or have been slandered, those who are ill ${ }^{63}$ and, as Lucretius says in 5.1017-1025, the weak. The Epicurean poet actually adds here that in the lives of primitive human beings pity represented an important boost for friendship and the civilizing process. The "weak" that are pitied in Lucretius' passage are babies, whom adults have sought to protect by making a pact with other people not to suffer or commit any act of injustice - in other words, by establishing justice and, more generally, the virtue of philanthropy that in turn fosters friendship ${ }^{64}$. If that is so, we could also add that pity contributes to the

61. $C f$. above section 1, p. $120 \mathrm{ff}$. The anonymous referee of the first draft of this essay proposed that the Epicureans might have recognized the positive role of forms of fear that guide us to self-preservation. Such are those that induce us to avoid any harmful or deadly object. He/She may be right, because Diogenes of Oenoanda (fr. 35, ed. Smith 1993) does hint at a distinction between clear forms of fear (e.g. seeing a fire or ferocious beast) and unclear ones, experienced by our mind when it is out of control (e.g. fears triggered by irrational beliefs on death and the divine). In any case, it is hardly true - at least for an Epicurean - that the terrifying visions of the tragic stage lead to self-preservation.

62. For this psychagogic method see again Epicurus, Fr.[52] = Diogenes Laertius, X 22. On the point that this action might actually be derived from courage, $c f$. Philodemus, $D$. III, fr. 79, edited and commented upon by Arrighetti 1955 p. 336.

63. Diogenes Laertius, X 118 ; Philodemus, Mort. 4, coll. 12.31-35, 24.10-17, 32.24-28 ; Lucretius, 6.1239-1234.

64. Stevens 1941, p. 430-432 ; Nussbaum 1994, p. 276 ; Radif 2004, p. 149. On the

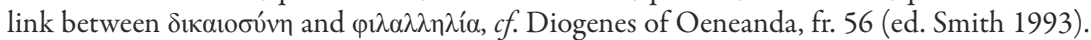
Notice also, on the one hand, that Epicurus thought that those who have suffered misfortunes must be helped, rather than be made an object of commiseration (Sent.Vat. 66). On the other hand, mind that, if pity implies philanthropy, philanthropy does not always entail pity ( $c f$. Diogenes Laertius, X 10; Philodemus, Elect. col. 14.1-7, ed. Indelli-Tsouna 1995; Diogenes of Oeneanda, frr. 2-3, 119). Here the Epicureans agree with Aristotle (see Po. 1453a1-4; Montmollin 1965; Bouchard 2012, p. 195-197). 
pleasurable life, since friendship is one of the most important elements for happiness and tranquillity ${ }^{65}$. Those who must not be pitied instead include the dead and wise human beings: namely, the "strong" and not the "weak" ones. For the former do not exist anymore, and hence are not subject to any misfortunes that could be pitied, while the latter can endure all the kind of harm that usually elicits pity ${ }^{66}$. Moreover, even when they die young (like the Epicurean Pythocles), wise men should be admired, for in their short life they appreciated the pure pleasures promised by Epicurus ${ }^{67}$.

Now, all these pieces of evidence and arguments show that the Epicureans probably rejected Aristotle's catharsis also for the following reason. If Oedipus or any other tragic character is similar yet superior to us in wisdom and virtue, why should he be pitied? If he is truly virtuous and wise, he could not be damaged by twist of fate and should not be pitied. By contrast, if the character did not possess perfect virtue and wisdom, the Epicureans would share his suffering and pity him, as well as try to help him, just as in the case of Lucretius' babies. However, they would not derive any moral betterment from this experience: for their strength only allows them to help the weaker members of their species. Hence, one of the most important elements for the catharsis of tragedy would appear to be missing. Even though Epicurus and his followers seem to consider pity an emotion that must not be removed completely, for it contributes to the pleasurable life by boosting friendship, it also seems to be an emotion that does not fit completely with virtue and wisdom. Therefore, it is not proper to induce this passion in order to improve people's moral character, for real wise characters deserve no pity and the contemplation of their fall is of no help for gaining happiness.

\subsection{Conclusions}

If the preceding considerations have any value, I believe that it can reasonably be concluded that the Epicureans rejected the sort of poetic catharsis described by Aristotle. Tragedy does not purify the passions that preclude a pleasurable life. Indeed, the misfortunes of tragic characters cannot provide any moral instructions, but rather show (falsely) that bad fortune influences our happiness, that the emotions which Aristotle considers harmful can be removed by rational teachings alone, that music and actors do not help the audience identify with what happens in a scene, and that fear and pity do not lead to virtue even if they are really reduced to a mean.

65. See at least Arrighetti 1978.

66. For a demonstration of this point, see Bignone 1973 vol. 1, p. 515-518.

67. Epicurus, Sent. XL; Philodemus, Mort.4, coll. 12.34-13.2 (= Metrodorus, fr. 63), 33.25-30, 35.34-36.23; Lucretius, 3.871-911; Stevens 1941, p. 433-434. Cf. also Carneiscus, coll. 16.1-17.14, where the Epicurean Philistas is remembered for his good life and is not pitied for having died, with Bignone 1973 vol. 1 ,p. 542-547; Capasso 1988, p. 40-54, 71-82; Tsouna 2007, p. 270-275; Armstrong 2016, p. 185-189. 
Such a conclusion allows us to infer that in all likelihood tragedy was not a genre cultivated by most Epicureans. There is no solida utilitas in this genre. And although it is true that we have evidence that at least the Epicurean Lucius Varius Rufus wrote some tragedies ${ }^{68}$, no fragments from his writings allow us to suppose that his creations tried to morally improve the audience. Our evidence actually makes it more probable that he shared the view of Boethus and his friends, namely that actors with the tragic mimesis of a suffering individual provide an interesting falsehood, the only purpose of which is to offer spectators a harmless divertissement.

\section{Lucretius' poetic honey: an Epicurean cathartic poetry?}

So far, the evidence that we have examined shows that catharsis was not linked to poetry in Greek Epicureanism and that in any case the Peripatetic theory of tragedy cannot account for the kind of poetic cleansing that I am searching for. There is, however, another path that remains open: poetic catharsis might have been allowed by the Roman Epicurean Lucretius. This author famously compared his poetry to the sweet and pleasurable honey of the Muses that induces the addressee - compared to a child scared by darkness - to imbibe the bitter wormwood of Epicurean philosophy or ratio (1.935-950). Such an image could be a way of referring to poetic catharsis. One could recall, for example, Olympiodorus' commentary on Plato's First Alcibiades, where the image of honey and wormwood is a metaphor for the кá $\theta \alpha \rho \sigma ı \varsigma$, provided by Socrates' reasoning ${ }^{69}$. Moreover, Lucretius' verses might also be considered a positive reinterpretation of the puerilis delectatio of poetry that Torquatus (ap. Cicero, Fin. I 21.71) condemned as unworthy of a philosopher like Epicurus. This childish pleasure that acts as a proper means to gain philosophical understanding would indeed appear useful for those who are not wise.

This point could be confirmed by the following arguments. Since Lucretius presents Epicurus' teaching as cathartic (cf. 5.18-21, 5.43-51, 6.24-34), and since he claims to be following in the footsteps of his Greek master (cf.e.g. 5.55: cuius ego ingressus vestigia), then his poetic verses must also be cathartic, owing to the fact that they reflect Epicurean philosophical doctrines. The catharsis of poetry is derived from the catharsis of philosophy.

Having established this, the following question remains to be answered: what kind of cathartic process is brought about by Lucretius' poetry? Though

68. Cf. frr. 153-158 of Hollis 2007.

69. Cf. I, p. 6.1-7; IV, p. 30.1-4; IX, p. 86.27-87.4. Note that Olympiodorus also qualifies Aristotle's catharsis as a way to purify opposites via opposites, specifically spirited emotions via appetites, and vice versa (cf. I, p. 6.9-11; VI, p. 54.15-55.1; these passages are absent from the collections of Gigon 1987). This is a really strange claim, which - to my knowledge - finds no parallel in extent Peripatetic writings. For more details, see Sorabji 2000, p. 297-299. 
the relationship between the Lucretian verses and Epicurean philosophy or ratio is a long-debated and difficult topic ${ }^{70}$, I believe that for my specific problem the following answer can be suggested. The fact that poetry may become cathartic by participation in Epicurean teachings implies that the only cathartic poetry is didactic poetry. In other words, the more poems aid philosophical teachings and arguments, the more cathartic they are. Poetry is cathartic when it assists philosophy.

This restriction rejects a priori forms of poetry that - as in the case of Aristotle's tragedy - involve emotion and imagination more than reason ${ }^{71}$. Nevertheless, it does not imply that only this kind of aesthetic activity is allowed by the Epicureans. Otherwise, a serious contradiction would arise with what in all likelihood was the orthodox Epicurean attitude toward poetry, as expressed in particularly by Philodemus, namely formalism: the appreciation of poetic expression for its form and of poets for their technique, rather than for the contents that they express ${ }^{72}$. The tension between this approach and the Lucretian praise of didactic poetry as something possibly cathartic can be avoided with the following supposition. Lucretius might have actually believed that his verses were cathartic not for their contents - deriving from Epicurus' philosophy - but precisely for their form. Asmis has indeed shown, for example, that Lucretian poetry struggles for clarity of expression ${ }^{73}$, while Armstrong has drawn attention to the fact that it seeks to consciously and skillfully position each letter / word, which is also one of the reasons for the impossibility of metathesis ${ }^{74}$. In other words, the qualification of didactic poetry as cathartic does not contradict formalism, because Lucretius focuses on the creation of the best possible poetic form and, in doing so, expresses the philosophical contents of Epicurus' teaching. This, in turn, will purify the listener / reader.

A final objection that must be addressed is that Lucretius cannot conceive his didactic poetry as completely devoid of emotional impact. Some scholars had argued that he even resorts to tragic emotions like pity and fear in certain

70. See at least Arragon 1961, p. 371-373; Schrijvers 1970, p. 27-47; Cox 1971, p. 10; Giancotti 1977, p. 46-65; Clay 1983, p. 45-49; Keen 1985, p. 7-8; Mitsis 1993; Kyriakou 1994; Erler 2003, p. 108-110; Radif 2004, p. 148-158; Konstan 2007, p. 72-73; Beer 2009, p. 436-460.

71. I am not saying here that Peripatetic catharsis is not rational, didactic or philosophical. This assertion would be contradicted by Aristotle's claims that mimesis (including tragic mimesis) is a kind of apprehension and that poetry is more philosophical than history (Po. $1448 \mathrm{~b} 4-20,1451 \mathrm{~b} 5-7)$. What I am arguing is that Peripatetic catharsis requires emotions as its essential means. This is not the case with strictly didactic poetry, which can exploit emotional responses but is not bound to do so.

72. E.g. Armstrong 1995, Asmis 1995b, Porter 1995. Doubts in Wigodsky 1995, p. 58.

73. Asmis 1995a, p. 34.

74. Armstrong 1995, p. 225-227. 
passages of his De rerum natura. This happens, e.g. when the poet describes the fearful and pitiful tales of the sacrifice of Iphigenia / the offspring of the sheep (1.62-101, 2.352-366), or the lamentations of people who are about to die (3.894-930), or the Athenian plague (6.1138-1286) ${ }^{75}$. This is true, but one must keep in mind that these passages may be interpreted as part of a poetical strategy that aims to show that Epicurean teachings will vanquish all the causes that make this fear and this pity possible, such as superstition. To state it differently, the fear and pity that arise from the telling of tales like the sacrifice of Iphigenia are not the final means to catharsis, just as in the Peripatetic tradition. They are just starting points for a poetic therapy. They are intense stories that prepare the audience to embrace the bitter medicine of Epicurus' teachings.

Nothing more can be said on the topic of Epicurean catharsis without embarking on wild speculation. The texts tell us nothing more and the historian of ancient philosophy is not allowed to go any further. If the hypotheses developed here are plausible, however, I think that they are enough to confirm the general interpretation of Epicureanism (mentioned at the beginning of the essay) as a philosophical movement that despises only those poems, poets and scholars of poetry (including Aristotle) that hinder rather than aid the achievement of the goal of pleasure. In this sense, poetic catharsis might be allowed by an Epicurean when it excludes excessive emotional involvement and boosts the efficiency of the cleansing power of reason.

75. See especially Else 1930, p. 163-167; Beer 2009 p. 485-491, p. 497. I agree with Stevens 1941, p. 427-428, that Lucretius' description of the wise man who views other people's misfortunes with iucunda voluptas (2.1-4) does not instead describe the pleasure of pity. For the difference between this feeling and '̌́ $\lambda \varepsilon 0 \varsigma$, see Ben-Ze'ev 2003, p. 115-118. 


\section{BIBLIOGRAPHY}

Adkins, A. W. H. 1966 : « Aristotle and the Best Kind of Tragedy », The Classical Quarterly, 16/1 (1966), p. 78-102.

Alberti, A. 2008 : «Ragione e virtù nell'etica epicurea », dans A. Alberti, L'arte del vivere. Aspetti dell'etica aristotelica ed epicurea, Genova, 2008, p. 175-205.

Anton, J. P. 1986 : « Mythos, Katharsis, and the Paradox of Tragedy », dans J. J. Cleary (éd.), Proceedings of the Boston Area Colloquium in Ancient Philosophy. Volume I, Lanham, 1986, p. 299-325.

Armstrong D. 1995 : « The Impossibility of Methatesis: Philodemus and Lucretius on Form and Content in Poetry », dans Oвbink 1995, p. 210-232.

Armstrong, D. 2016 : «Utility and Affection in Epicurean Friendship : Philodemus On the Gods 3, On Property Management, and Horace, Sermones 2. 6 », dans R. Caston, R. Kaster (éd.), Hope, Joy and Affection in the Classical World, Oxford, 2016, p. 182-207.

Arragon, R. F. 1961 : « Poetic Art as Philosophic Medium for Lucretius », Essays in Criticism, 11/4 (1961), p. 371-389.

Arrighetti, G. 1955 : « Filodemo ПEPI $\Theta E \Omega N$ III fr. 74-82. PHerc. 157 », La parola del passato, 44 (1955), p. 322-356.

Arrighetti, G. 1961 : «Filodemo, De diis III col. XII-XIII 20 (quasi corpus, quasi

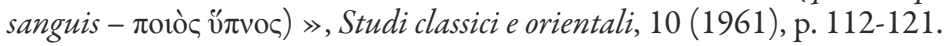

Arrighetti, G. 1973 (éd.) : Epicuro, Opere, nuova edizione riveduta e ampliata, Torino, 1973.

Arrighetti, G. 1978 : «Philia e Physiologia : i fondamenti dell'amicizia epicurea », Materiali e discussioni per l'analisi dei testi classici, 1 (1978), p. 49-63.

Arrighetti, G. 1998 : « Gli Epicurei, la poesia e Lucrezio », Athenaeum, 86/1 (1998), p. 13-33.

ArrighetTI, G. 2000 : « Filodemo fra poesia, mito e storia », dans M. Erler (éd.), Epikureismus in der späten Republik und der Kaiserzeit, Stuttgart, 2000, p. 13-31.

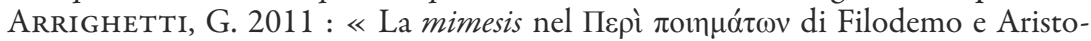
tele », Cronache Ercolanesi, 41 (2011), p. 69-82.

Asmis, E. 1995a : «Epicurean Poetics », dans ObBink 1995, p. 15-34.

Asmis, E. 1995b : « Philodemus on Censorship, Moral Utility, and Formalism in Poetry », dans Obbink 1995, p. 148-177.

Asmis, E. 2009 : « Basic Education in Epicureanism », dans Y. Lee Too (éd.), Education in Greek and Roman Antiquity, Leiden, 2009, p. 209-239.

BAILey, C. 1926 (éd.) : Epicurus: The Extant Remains, Oxford, 1926.

Beer, B. 2009 : Lukrez und Philodem. Poetische Argumentation und poetologischer Diskurs, Basel, 2009.

Belfiore, E. S. 1985 : « Tragedy and Aristotelian Psychology », The Classical Quarterly, 35/2 (1985), p. 349-361.

Belfiore, E. S. 1992 : Tragic Pleasures, Princeton, 1992.

BEN-ZE'EV, A. 2003 : « Aristotle on Emotions Towards the Fortune of Others », dans D. Konstan, N. K. Rutter (éd.), Envy, Spite and Jealousy. The Rivalrous Emotions in Ancient Greece, Edinburgh, 2003, p. 99-121. 
Bernays, J. 1857 : Grundzüge der verlorenen Abhandlung des Aristoteles über Wirkung der Tragödie, Breslaw, 1857.

Bignone, E. 1973 : L'Aristotele perduto e la formazione filosofica di Epicuro, 2 vol., Firenze, 1973. [Firenze, 1936.]

Bouchard, E. 2012 : « Audience, Poetic Justice, and Aesthetic Value in Aristotle's Poetics », dans SLuiter \& Rosen 2012, p. 183-213.

BRADy, M. E. 2005 : « The Fearlessness of Courage », The Southern Journal of Philosophy, 43 (2005), p. 189-211.

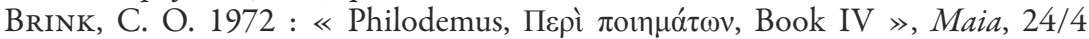
(1972), p. 342-344.

Brown, R. D. 1987 : Lucretius on Love and Sex: a Commentary on De rerum natura 4.1030-1287, Leiden, 1987.

Capasso, M. 1988 (éd.) : Carneisco : Il secondo libro del Filista (PHerc. 1027), Napoli, 1988.

Clay, D. 1983 : Lucretius and Epicurus, Ithaca-London, 1983.

Cooper, L. 1956 : The Poetics of Aristotle, its Meaning and Influence, Ithaca-New York, 1956.

Cox, A. S. 1971 : « Lucretius and His Message: A Study in the Prologues of the De Rerum Natura », Greece \& Rome, 18/1 (1971), p. 1-16.

CRISP, R. 2008 : «Compassion and Beyond », Ethical Theory and Moral Practice, $11 / 3$ (2008), p. 233-246.

Delattre, D. 2007 (éd.) : Philodème de Gadara. Sur la musique. Livre IV, 2 vol., Paris, 2007.

Delattre, D. 2009 : « Le sage épicurien face à la colère et à l'ivresse : une lecture renouvelée du De ira de Philodème », Cronache Ercolanesi, 39 (2009), p. 71-88.

Delattre, J. \& D. Delattre 1994 : « Musique, plaisir et philosophie : orthodoxie et modernité de Philodème », dans L. Jerphagnon, J. Lagrée, D. Delattre (éd.), Ainsi parlaient les anciens. In honorem Jean-Paul Dumont, Paris, 1994, p. 163-174.

Deslauriers, M. 2003 : Aristotle on Andreia, Divine and Sub-Human Virtues, dans R. M. Rosen, I. Sluiter (éd.), 'Andreia'. Studies in Manliness and Courage in Classical Antiquity, Leiden-Boston, 2003, p. 187-211.

Destrée, P. 2012 : « Le plaisir "propre” de la tragédie est-il intellectuel ? », dans Malhomme-Miletti-Rispoli-Zagdoun 2012, p. 41-54.

Diels, H. 1970 (éd.) : Philodemos, 'Über die Götter' : erstes und drittes Buch, 2 vol., Leipzig, 1970. [Berlin 1916-1917.]

Diano, C. 1974 : « La psicologia di Epicuro e la teoria delle passioni », dans C. Diano, Scritti epicurei, Firenze, 1974, p. 129-280.

Donini, P. L. 2004 : La tragedia e la vita. Saggi sulla Poetica di Aristotele, Alessandria, 2004.

Donini, P. L. 2008 : « Aristotele : a chi e a che cosa serve una tragedia », dans F. Alesse et al. (éd.), Anthropine sophia.' Studi di filologia e storiografia filosofica in memoria di Gabriele Giannantoni, Napoli, 2008, p. 351-377.

ElSE, G. F. 1930 : « Lucretius and the Aesthetic Attitude », Harvard Studies in Classical Philology, 41 (1930), p. 149-182.

Else, G. F. 1986 : Plato and Aristotle on Poetry, Chapel Hill-London, 1986. 
Erler, M. 2003 : « Das Bild vom “Kind im Menschen” bei Platon und der Adressat von Lukrez De rerum natura », Cronache Ercolanesi, 33 (2003), p. 107-116.

Essler, H. 2011 : Glückselig und unsterblich. Epikureische Theologie bei Cicero und Philodem, Basel, 2011.

Essler, H. 2016 : « Ehebruch bei Göttern und Steinen (PHerc. 152/157, Frg. 42, 25-Frg. 78, 9) », Cronache Ercolanesi, 46 (2016), p. 101-108.

FHS\&G. 1992 = W. W.Fortenbaugh, P. M. Huby, R. W. Sharples, D. Gutas 1992 (éd.) : Theophrastus of Eresus: Sources for His Life, Writings, Thought and Influence, 2 vol., Leiden-New York-Köln, 1992.

Flashar, H. 1956 : « Die Medizinischen Grundlagen der Lehre von der Wirkung der Dichtung in der Griechischen Poetik », Hermes, 84/1 (1956), p. 12-48.

Ford, A. L. 2004 : « Catharsis: The Power of Music in Aristotle's Politics », dans P. Murray, P. Wilson (éd.), Music and the Muses. The Culture of "Mousike" in the Classical Athenian City, Oxford, 2004, p. 309-336.

Fortenbaugh, W. W. 2002 : Aristotle on Emotion, London, 2002.

Fortenbaugh, W. W. 2005 (éd.) : Theophrastus of Eresus. Vol. 8: Sources on Rhetoric and Poetics (Texts 666-713), Leiden-Boston, 2005.

FrAZIER, F. 2012 : «La spécificité du concept aristotélicien de muthos. Une relecture de la Poétique », dans Malhomme-Miletti-Rispoli-Zagdoun 2012, p. 103-124.

Gargiulo, T. 1979 : «PHerc. 222 : Filodemo Sull'adulazione », Cronache Ercolanesi, 11 (1981), p. 103-127.

Gentilucci, P. 1997 : « Il poema scientifico nel pensiero degli Epicurei del I secolo a. C. », dans S. Sconocchia, L. Toneatto (éd.), Lingue tecniche del greco e del latino, II, con la collaborazione di D. Crismani, M. Faraguna, I. Pin, Bologna, 1997, p. 49-70.

Gercke, A. 1885 : « Chrysippea », Jahrbücher für klassische Philologie, 14 (1885), p. $691-781$.

Giancotti, F. 1978 : Il preludio di Lucrezio, e altri scritti lucreziani ed epicurei, Messina-Firenze, 1978.

Giannantoni, G. \& M. Gigante 1996 (éd.) : Epicureismo greco e romano, 2 vol., Napoli, 1996.

Gigante, M. 1975 : « Philosophia medicans in Filodemo », Cronache Ercolanesi, 5 (1975), p. 53-61.

Gigante, M. 1993 : «Filodemo contro Aristotele », dans M. Gigante, Atakta. Contributi alla papirologia ercolanese, vol. I, a cura di F. Tessitore, Napoli, 1993, p. 132-134.

Gigante, M. 1999 : Kepos e Peripatos, Napoli, 1999.

Gigon, O. 1987 (éd.) : Aristoteles, Librorum deperditorum fragmenta, Berlin, 1987.

Glanville, I. M. 1949 : «Tragic Error », The Classical Quarterly, 43.1-2 (1949), p. 47-56.

Golden, L. 1992 : Aristotle on Tragic and Comic 'Mimesis', Atlanta, 1992.

Greenberg, N. A. 1990 : The Poetic Theory of Philodemus, New York-London, 1990.

Guastini, D. 1999 : Come si diventa uomini. Etica e poetica nella tragedia greca, Roma, 1999. 
Guastini, D. 2003 : Prima dell'estetica. Poetica e filosofia nell'antichità, Roma-Bari, 2003.

Guastini, D. 2010 (éd.) : Aristotele, Poetica, Roma, 2010.

Halliwell, S. 2002 : The Aesthetics of 'Mimesis'. Ancient Texts and Modern Problems, Princeton and Oxford, 2002.

Halliwell, S. 2011 : Between Ecstasy and Truth. Interpretations of Greek Poetics from Homer to Longinus, Oxford, 2011.

Hammerstaedt, J. 1997 : «Pausone, Aristofane e Archiloco nel quarto libro Пepì

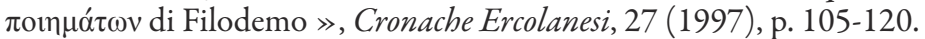

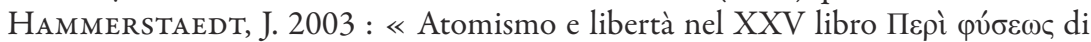
Epicuro », Cronache Ercolanesi, 33 (2003), p. 151-158.

Hammerstaedt, J., M. S. Smith (éd.) 2014 : The Epicurean Inscription of Diogenes of Oinoanda. Ten years of new discoveries and research, Bonn, 2014.

Heath, M. 2003 : « Aristotle and the Pleasures of Tragedy », dans J. Andersen, Ø. Haarberg (éd.), Making Sense of Aristotle. Essays in 'Poetics', London, 2003, p. 7-23.

Heath, M. 2013 : Ancient Philosophical Poetics, Cambridge, 2013.

Heil, J. F. 1996 : « Why is Aristotle's Brave Man So Frightened ? The Paradox of Courage in the Eudemian Ethics », Apeiron, 29/1 (1996), p. 47-74.

Heinaman, R. 1985 : «Eudaimonia and Self-Sufficiency in the Nicomachean Ethics », Phronesis, 33/1 (1988), p. 31-53.

Henry, B. 2009 (éd.) : Philodemus, On Death, Atlanta, 2009.

Hollis, A. S. 2007 (éd.) : Fragments of Roman Poetry c. 60 BC-AD 20, Oxford, 2007.

Indelli, G. \& V. Tsouna 1995 (éd.) : Philodemus, On Choices and Avoidances, Napoli, 1995.

Janko, R. 1992 : «From Catharsis to the Aristotelian Mean », dans Oksenberg Rorty 1992a, p. 341-358.

Janko, R. 2000 (éd.) : Philodemus, On poems (Books 1-2), Oxford, 2000.

Janko, R. 2011 (éd.) : Philodemus, On Poems (Books 3-4), Oxford, 2011.

Jannone, A. 1996 : « La polemica di Epicuro contro Aristotele », dans GiannanTONI-Gigante 1996, vol. 1, p. 87-98.

Jones, E. M. 2012 : « Allocating Musical Pleasure : Performance, Pleasure, and Value in Aristotle's Politics », dans SLuiter-Rosen 2012, p. 159-182.

KeEn, R. 1985 : « Lucretius and His Reader », Apeiron, 1 (1985), p. 1-10.

KIM, H. 2010 : « Aristotle's 'Hamartia' Reconsidered », Harvard Studies in Classical Philology, 105 (2010), p. 33-52.

Koch, R. 2005: Comment peut-on être dieu ? La secte d'Épicure, Paris, 2005.

Koller, H. 1954 : Die Mimesis in der Antike, Bern, 1954.

Konstan, D. et alii 1998 (éd.) : Philodemus, On Frank Criticism, Atlanta, 1998.

Konstan, D. 2001 : Pity Transformed, London, 2001.

Konstan, D. 2005 : « Aristotle on the Tragic Emotions », dans V. Pedrick, S. M. Oberhelman (éd.), The Soul of Tragedy. Essays on Athenian Drama, Chicago-London, 2005, p. 13-26.

KOnSTAN, D. 2007 : Lucrezio e la psicologia epicurea, nuova edizione italiana a cura di I. Ramelli, Milano, 2007. [1 ${ }^{\text {ìre }}$ éd. : Some Aspects of Epicurean Psychology, Leiden, 1973.] 
KöRTE, A. 1890 (éd.) : Metrodori Epicurei Fragmenta, Leipzig, 1890.

Kyriakou, P. 1994 : « Lucretius' Atomic Poetics », dans C. Deroux (éd.), Studies in Latin Literature and Roman History, vol. VII, Bruxelles, 1994, p. 206-210.

Laursen, S. 1995 : «The Early Parts of Epicurus, On Nature, $25^{\text {th }}$ Book », Cronache Ercolanesi, 25 (1995), p. 5-109.

Laursen, S. 1997 : « The Later Parts of Epicurus, On Nature, $25^{\text {th }}$ Book », Cronache Ercolanesi, 27 (1997), p. 5-83.

Lear, J. 1992 : « Katharsis », dans Oksenberg Rorty 1992a, p. 315-340.

LEAR, J. 1995 : « Testing the limits: the place of tragedy in Aristotle's ethics », dans R. Heinaman (éd.), Aristotle and Moral Realism, London, 1995, p. 61-84.

Leighton, S. 2003 : « Aristotle's Exclusion of Anger from the Experience of Tragedy », Ancient philosophy, 23 (2003), p. 361-381.

Leone, G. 2002 : « Epicuro, Della natura, libro XXXIV (Pherc. 1431) », Cronache Ercolanesi, 32 (2002), p. 7-135.

Liebersohn, Y. Z. 2015 : «Epicurus' "Kinetic" and "Katastematic" Pleasures. A reappraisal », Elenchos, 36/2 (2015), p. 271-296.

Longo Auricchio, F. 1988 (éd.) : Ermarco, Frammenti, Napoli, 1988.

Malhomme, F., L. Miletti, G. M. Rispoli \& M.-A. Zagdoun 2012 (éd.) : Renaissances de la tragédie. La Poétique d'Aristote et le genre tragique, de l'Antiquité à l'époque contemporaine, Paris, 2012.

Mangoni, C. 1993 (éd.) : Filodemo, Il quinto libro della Poetica (PHerc. $1425 e$ 1538), Napoli, 1993.

MARINO, E. 1999 : « Il teatro e il suo doppio: comunicazione teatrale e scrittura », dans A. Camerotto, R. Oniga (éd.), La parola nella città. Studi sulla ricezione del teatro antico, Udine, 1999, p. 11-33.

Matelli, E. 2012 (éd.) : « Praxiphanes of Mytilene (called "of Rhodes"). The Sources, Text and Translation » dans A. Martano, E. Matelli, D. Mirhady (éd.), Praxiphanes of Mytilene and Chamaeleon of Heraclea : text, translation, and discussion, New Brunschwig, 2012, p. 1-156.

McCoy, M. B. 2013 : « Tragedy, Katharsis, and Community in Aristotle's Poetics », dans M. B. McCoy (éd.), Wounded Heroes. Vulnerability as a Virtue in Ancient Greek Philosophy and Literature, Oxford, 2013, p. 169-203.

Mitsis, P. 1993 : «Committing Philosophy on the Reader : Didactic Coercion and Reader Autonomy in De Rerum Natura », dans A. Schiesaro, P. Mitsis, J. Strauss Clay (éd.), 'Mega nepios': Il destinatario nell'epos didascalico, Pisa, 1993, p. 111-128.

Mitsis, P. 2014 : L'Éthique d'Épicure. Les plaisirs de l'invulnérabilité, trad. A. Gigandet, Paris, 2014. [ 1 ìre éd. Epicurus'Ethical Theory. The Pleasures of Invulnerability, Ithaca-London, 1988.]

Montmollin, D. de 1965 : « Le sens du Terme $\Phi \mathrm{I} \Lambda \mathrm{AN} \Theta \mathrm{P} \Omega \Pi \mathrm{ON}$ dans la Poétique d'Aristote », Phoenix, 19/1 (1965), p. 15-23.

Nardelli, M. L. 1978 : « La catarsi poetica nel PHerc. 1581», Cronache Ercolanesi, 8 (1978), p. 96-103.

Nehamas, A. 1992 : «Pity and Fear in the Rhetoric and the Poetics », dans OKsenBERG RORTY 1992a, p. 291-314.

Nussbaum, M. C. 1992 : « Tragedy and Self-Sufficiency: Plato and Aristotle on Fear and Pity », Oxford Studies in Ancient Philosophy, 10 (1992), p. 107-159. 
Nussbaum, M. C. 1994 : The Therapy of Desire: Theory and Practice in Hellenistic Ethics, Princeton, 1994.

Nussbaum, M. C. 2001 : The Fragility of Goodness : Luck and Ethics in Greek Tragedy and Philosophy, Cambridge, 2001. [1986.]

Оввіnк, D. 1995 (éd.) : Philodemus and Poetry. Poetic Theory and Practice in Lucretius, Philodemus and Horace, Oxford, 1995.

Obbink, D. 1996 (éd.) : Philodemus, On Piety, Part I, Oxford, 1996.

Oksenberg Rorty, A. 1992a (éd.) : Essays on Aristotle's 'Poetics', Princeton, 1992.

Oksenberg Rorty, A. 1992b : « The Psychology of Aristotelian Tragedy », dans Oksenberg Rorty 1992a, p. 11-22.

Østerud, S. 1976 : « Hamartia in Aristotle and Greek tragedy », Symbolae Osloenses, 51/1 (1976), p. 65-80.

PACE, N. 2005 : « Religione ed etica nel NF 126 Smith di Diogene di Enoanda », Cronache Ercolanesi, 35 (2005), p. 201-209.

PACE, N. 2009 : « La poetica epicurea di Filodemo di Gadara », Rheinisches Museum für Philologie, 152/3-4 (2009), p. 235-264.

PACK, R.A. 1937 : «A Passage in Alexander of Aphrodisias Relating to the Theory of Tragedy », The American Journal of Philology, 58/4 (1937), p. 418-436.

Palumbo, L. 2008 : Mímolৎ. Rappresentazione, teatro e mondo nei dialoghi di Platone e nella Poetica di Aristotele, Napoli, 2008.

Pears, D. 1978 : « Aristotle's Analysis of Courage », Midwest Studies in Philosophy, 3 (1978), p. 273-285.

PeARs, D. 1980 : « Courage as a Mean », dans A. Oksenberg Rorty (éd.), Essays on Aristotle's Ethics, Berkeley, 1980, p. 171-187.

Pesce, D. 1981 (éd.) : Aristotele, La poetica, Milano, 1981.

Piergiacomi, E. 2017 : Storia delle antiche teologie atomiste, Roma, 2017.

Porter, J. I. 1995 : « Content and Form in Philodemus : The History of an Evasion », dans OBBink 1995, p. 97-147.

Porter, J. I. 1996 : « In Search of an Epicurean Aesthetics », dans GiannantoniGigante 1996, vol. 2, p. 611-628.

RADIF, L. 2004 : « Richiami all'infanzia come metodo pedagogico-poetico (Plat. Leg. [790c], Lucr. II 55-58) », Giornale di Metafisica, 26 (2004), p. 139-160.

Ranocchia, G. 2007 (éd.) : Aristone. Sul modo di liberare dalla superbia nel decimo libro De vitiis di Filodemo, Firenze, 2007.

Rapp, C. 2009 : « Aristoteles über das Wesen und die Wirkung der Tragödie », dans O. Höffe (éd.), Aristoteles, Poetik, Berlin, 2009, p. 89-104.

RASHED, M. 2016 : « Katharsis versus mimesis : simulation des émotions et définition aristotélicienne de la tragédie », Littérature, 182/2 (2016), p. 60-77.

Reeves, C. H. 1952 : « The Aristotelian Concept of the Tragic Hero », American Journal of Philology, 73/290 (1952), p. 172-188.

Rispoli, G. M. 2005 : «Tragedia e tragici nei papiri ercolanesi », Vichiana, 7/1 (2005), p. 195-230.

Rispoli, G. M. 2012 : « L'Aristotele ercolanese. Aristotele e aristotelismo sulla tragedia nei papiri di Ercolano », dans Malhomme-Miletti-Rispoli-ZAGDOUN 2012, p. 239-270.

Rogers, K. 1994 : « Aristotle on the Motive of Courage », The Southern Journal of Philosophy, 32 (1994), p. 303-313. 
Romeo, C. 1988 (éd.) : Demetrio Lacone, La poesia (PHerc. 188 e 1014), Napoli, 1988.

Roskam, G. 2011 : « Reading Fables in Epicurus' Garden. On Metrodorus, fr. 60 K. », Cronache Ercolanesi, 41 (2011), p. 33-36.

Saintillan, D. 2003 : «Éducation morale et catharsis tragique », Les Études philosophiques, 66 (2003), p. 518-540.

SCHAPer, E. 1968 : « Aristotle's Catharsis and Aesthetic Pleasure », The Philosophical Quarterly, 18/71 (1968), p. 131-143.

SCHRIJVERS, P. H. 1970 : Horror ac divina voluptas, Amsterdam, 1970.

ScotT, D. 2000 : « Aristotle on Posthumous Fortune », Oxford Studies in Ancient Philosophy, 18 (2000), p. 211-229.

Scotт, G., 2003 : « Purging the Poetics », Oxford Studies in Ancient Philosophy, 25 (2003), p. 233-263.

Sherman, N. 1992 : « Hamartia and Virtue », dans Oksenberg Rorty 1992a, p. 77-196.

Sider, D. 1995 : « Epicurean Poetics : Response and Dialogue », dans Obbink 1995 , p. 35-41.

Sluiter, I. \& R. M. Rosen 2012 (éd.) : Aesthetic Value in Classical Antiquity, Leiden-Boston, 2012.

Smith, M. F. 1993 (éd.) : Diogenes of Oenoanda, The Epicurean Inscription, Napoli, 1993.

Sorabji, R. 1980 : Necessity, Cause and Blame : Perspectives on Aristotle's Theory, Ithaca-New York, 1980.

SorabjI, R. 2000 : Emotion and Peace of Mind: From Stoic Agitation to Christian Temptation, Oxford, 2000.

Stevens, E. B. 1941 : « Topics of Pity in the Poetry of the Roman Republic », The American Journal of Philology, 62/4 (1941), p. 426-440.

Stinton, T. C. W. 1975: « Hamartia in Aristotle and Greek Tragedy », The Classical Quarterly, 25/2 (1975), p. 221-254.

Sudhaus, S. 1964 (éd.) : Philodemus, Volumina Rhetorica, 3 vol., Amsterdam, 1964.

Tepedino Guerra, A. : «Il primo libro Sulla ricchezza di Filodemo », Cronache Ercolanesi, 8 (1978), p. 52-95.

Tepedino Guerra, A. 1991 (éd.) : Polieno. Frammenti, Napoli, 1991.

Tsitsiridis, S. 2005 : « Mimesis and Understanding : An Interpretation of Aristotle's Poetics 4. 1448B4-19 », The Classical Quarterly, 55/2 (2005), p. 435-446.

Tsouna, V. 2003 : « "Portare davanti agli occhi": una tecnica retorica nelle opere "morali" di Filodemo », Cronache Ercolanesi, 33 (2003), p. 243-247.

Tsouna, V. 2007 : The Ethics of Philodemus, Oxford, 2007.

Tsouna, V. 2016 : «Epicurean Preconceptions », Phronesis, 61 (2016), p. 160-221.

UGolini, G. 2012 : Jacob Bernays e l'interpretazione medica della catarsi tragica, Verona, 2012.

Untersteiner, M. 1955 : Le origini della tragedia e del tragico. Dalla preistoria a Eschilo, Torino, 1955.

Veloso, C. W. 2007 : « Aristotle's Poetics without katharsis, fear, or pity », Oxford Studies in Ancient Philosophy, 33 (2007), p. 255-284.

VERDE, F. 2013a : « La felicità aristotelica tra la morte e la sorte: note di commento ad Aristotele, Etica Nicomachea I 11 »,Lexicon Philosophicum, 1 (2013), p. 258-275. 
Verde, F. 2013b : « TҮXH e $\Lambda$ OГI $\Sigma M O \Sigma$ nell'Epicureismo », dans F. G. Masi \&

S. Maso (éd.), Fate, Chance and Fortune in Ancient Thought, Amsterdam, 2013, p. 177-197.

Verde, F. 2015 : «Boethus the Epicurean », Philosophie antique, 15 (2015), p. 205-224.

Warren, J. 2004 : Facing Death, Cambridge, 2004.

Warren, J. 2013 : « Epicureans and Cyrenaics on Pleasure as a Pathos », dans S. Marchand, F. Verde (éd.), Épicurisme et Scepticisme, Roma, 2013, p. 122-140.

Watson, I. 1988 : «Catharsis and the Actor », New Theatre 2uarterly, 16/4 (1988), p. 306-314.

Wehrli, F. 1967 (éd.) : Die Schule des Aristoteles. Band 2: Aristoxenos, Basel-Stuttgart, 1969.

Wigodsky, M. 1995 : « The Alleged Impossibility of Philosophical Poetry », dans Оввілк 1995, p. 58-68. 